\title{
THE FEMINIST CHALLENGE IN CRIMINAL LAW
}

\section{STEPHEN J. SCHULHOFER†}

\section{INTRODUCTION}

Feminist criticism of criminal law and criminal justice administration has proliferated over the past decade and now touches scores of doctrinal, practical, and theoretical issues. These critiques and the associated proposals for reform are usually acknowledged to be controversial (and even "radical") by proponents and opponents alike. Yet, across a wide range of issues, the feminist position has its basis in a simple fact that cannot be considered debatable: criminal law is, from top to bottom, preoccupied with male concerns and male perspectives.

In this Article, I explain why this seemingly tendentious claim is not only accurate but uncontroversial. I then seek to show how the male orientation of existing criminal law creates both the necessity for reform and a major obstacle to doing it well.

The feminist challenge is to adapt male-oriented criminal laws and practices to the concerns of a group of victims and offenders who are normally left out of the picture. This turns out to be difficult, and not just because of a lack of empathy for the needs of women. Factoring female victims and female offenders into the criminal law equation is hard because of many conflicting concerns and commitments that most Americans share. Three conflicts in particular will be central to the discussion that follows.

First, although we want women to be treated the same as men, sometimes equality cannot be achieved by treating two groups of people the same way. We need to take differences into account.

† Julius Kreeger Professor of Law and Criminology and Director of the Center for Studies in Criminal Justice, University of Chicago. Portions of this Article were presented at McGeorge Law School in November 1994, at the Annual Meeting of the American Political Science Association in September 1994, and at the University of Chicago Law School in November 1993 as the Wilbur G. Katz Lecture. Research for this Article was supported by the Russell J. Parsons Faculty Research Fund and the Sonnenschein Fund at the University of Chicago Law School. I have also benefited from the research assistance of Kimberly Dunn and Katharine Moir, and from the comments of Kathryn Abrams, Albert Alschuler, Mary Coombs, Anne Coughlin, Deborah Denno, Joshua Dressler, Leslie Goldstein, Elena Kagan, Dan Kahan, Jane Larson, Larry Lessig, Dorothy Roberts, Cass Sunstein, Michael Vitiello, Joan Williams, and Laurie Wohl. 
Yet drawing categorical distinctions between men and women undermines our ideals. This is the familiar debate concerning sameness versus difference. It pervades discussions of gender in other areas of the law and discussions of equal treatment for racial minorities, the handicapped, and other groups. ${ }^{1}$ The debate plays out with some unexpected twists in criminal justice.

A second dilemma is that we want to be sensitive to the nuances of context when gender issues are at stake. But effective protection of women also requires that women have clear-cut rights protected by clear rules. This is the old debate concerning rules versus discretion. Again, it plays out with some unexpected twists in criminal justice.

A third dilemma concerns the limits of theory. We need theory to help pinpoint the problems confronting women and to help organize thinking about solutions. But theory is not up to the task. Indeed, I will argue that in criminal justice, theory can never be equal to the task.

Much of contemporary feminist discussion and scholarship center on developing new theories or on parsing the differences among theories and defending commitments to one of them or another. One theory emphasizes formally equal treatment. ${ }^{2} \mathrm{~A}$ major competitor is a theory stressing the ways that culture and social practice subordinate women under laws that are formally neutral. ${ }^{3}$ A third theory emphasizes context, caring, and connection in lieu of what it views as a "male" commitment to abstract rights defined without regard to context. ${ }^{4}$ One scholar has iden-

${ }^{1}$ See, e.g., MARTHA MINOW, MAKING ALl THE DifferenCE: INCLUSION, EXCLUSION, AND AMERICAN LAW 21 (1990) ("The dilemma of difference grows from the ways in which this society assigns individuals to categories and, on that basis, determines whom to include in and whom to exclude from political, social, and economic activities.").

${ }^{2}$ See, e.g., Wendy W. Williams, The Equality Crisis: Some Reflections on Culture, Courts, and Feminism, 7 WOMEN's RTS. L. REP. 175, 175 (1982) (stating that courts should "rule that the privileges the law explicitly bestows on men must also be made available to women"); Wendy W. Williams, Notes from a First Generation, 1989 U. CHI. LEGAL F. 99, 99 (identifying the "formal' equality" approach as "an insistence that laws not embody explicit sex-based distinctions").

3 See, e.g., CATHARINe A. MACKInNon, FEminism Unmodified: Discourses on LIFE AND LAW 40 (1987) (discussing the "dominance approach" to the equality question); Christine A. Littleton, Reconstructing Sexual Equality, 75 CAL. L. REv. 1279, 1282-84 (1987) (noting that courts routinely apply "phallocentric standards 'equally' to men and women's different reproductive biology or economic position to yield . . . unequal results for women").

${ }^{2}$ See, e.g., Carol Gilligan, In a Different Voice: Psychological Theory and 
tified seven distinct feminisms: liberal, radical, marxist, socialist, psychoanalytic, existentialist, and post-modern. ${ }^{5}$ And that taxonomy still leaves out a few. ${ }^{6}$ We can say, with only slight exaggeration, that feminist legal theory and feminist jurisprudence have become synonyms for feminist scholarship in law schools today:

I do not attempt here to define and distinguish the many varieties of feminist theory because I wish to draw attention to a problem that is common to all of them. The difficulty, not a new one, is that broad propositions do not solve concrete cases; or they solve too many cases very poorly. The problems confronting women in criminal justice run so deep and have such complex links to the goals and structures of law that theory is inherently incapable of carrying us very far along the path toward effective solutions. The problems can be worked out only by paying close attention to particulars.

I begin this Article by describing how the criminal justice system is dominated (incontrovertibly so) by a preoccupation with men and male perspectives. I then focus on four problems that particularly concern women as potential victims or offendersdomestic violence, rape, sentencing policy, and prisons. Finally, drawing some common lessons from the four discussions, I suggest the need for a rather skeptical attitude toward high theory in the

WOMEN'S DEVELOPMENT 17 (1982) (discussing the importance of the ethic of care to women's self-definition).

${ }^{5}$ See ROSEMARIE TONG, Feminist Thought: A COMPREHENSIVE INTRODUCTION $1-8$ (1989).

${ }^{6}$ See, e.g., Katharine T. Bartlett, Feminist Legal Methods, 103 HARV. L. REv. 829, 836-67 (1990) (discussing feminist practical reasoning, consciousness-raising, and related methods of epistemological inquiry).

${ }^{7}$ There are, to be sure, significant counterexamples: some recent legal scholarship considers potential reform with a close eye on the institutional or doctrinal specifics of legal change. See, e.g., Mary E. Becker, Politics, Differences and Economic Rights, 1989 U. CHI. LEGAL F. 169, 171 (discussing the economic effects of formal equality); Herma H. Kay, Equality and Difference: A Perspective on No-Fault Divorce and Its Aftermath, 56 U. CIN. L. REv. 1, 3 (1987) (exploring the concrete effect of no-fault divorce reforms); Jane E. Larson, "Women Understand So Little, They Call My Good Nature 'Deceit'": A Feminist Rethinking of Seduction, 93 CoLUM. L. REv. 374, 454-71 (1993) (examining specific elements of a legal cause of action for sexual fraud); Deborah L. Rhode, Feminism and the State, 107 HARV. L. REv. 1181, 1195, 1197-98 (1994) (focusing on institutional details necessary to promote feminist goals in the areas of physical security and equal employment opportunity). A related example, largely pragmatic in tone, although not as detailed in its reform prescriptions, is SUSAN ESTRICH, REAL RAPE 80-91 (1987) (discussing various reform statutes focusing on the problem of rape). 
search for a feminism that can guide reform in criminal justice and, perhaps, other areas. Despite the undoubted importance of theoretical insight, the most effective tools of reform at the present juncture are likely to be eclectic and atheoretical, and the most effective feminist scholarship is likely to be one that attends to the complexities of specific institutions and procedures. What is needed, I suggest, is a feminism of particulars, a recognition that real solutions are likely to lie deeply embedded in the details.

\section{Why CRIMINAL LAW Is "MALE"}

The criminal justice system fits almost perfectly Lincoln's conception of a government of the people, by the people, and for the people. It fits perfectly, if you are willing to equate "the people" with the male half of the population. Criminal law is-and has been for centuries-a system of rules conceived and enforced by men, for men, and against men.

There are counterexamples but not many. The law against prostitution, which might make sense as a way to protect young and poor women from sexual exploitation, is not enforced that way. It is enforced almost exclusively against women. ${ }^{8}$ The law notices women but prosecutes those it should be protecting. In many instances law enforcement does benefit and protect women. But overwhelmingly, criminal law is designed and implemented with men in mind.

This observation should be considered completely uncontroversial. One way for the reader to confirm its accuracy is simply to pause for a moment and attempt to picture a typical offender. What does he look like? $\mathrm{He}$ is inevitably the subject of the inquiry. The criminal offender is disproportionately male, overwhelmingly so. In 1983, men and boys, $49 \%$ of the U.S.

${ }^{8}$ See, e.g., RiCHARd SYMANSKI, THE IMMORAL LANDSCAPE: FEMALE Prostitution IN WESTERN SOCIETIES 88 (1981) (noting that although New York law was changed in 1964 to criminalize both male prostitution and the act of patronizing a prostitute, the effect of the change was minimal; in 1977, the number of males arrested was less than one-tenth the number of females arrested). Recent attention to the need for sanctioning prostitutes' customers has not substantially changed this picture. See Eleanor M. Miller et al., The United States, in PrOStitution: AN INTERNATIONAL HANDBOOK ON TRENDS, PROBlems, AND Policies 300, 313 (Nanette J. Davis ed., 1993) (noting the persistence of arrest patterns in which $70 \%$ of prostitution arrests are of females, while male customers account for only about $10 \%$ of arrests). 
population, represented $78 \%$ of all property offenders and $89 \%$ of all violent offenders. ${ }^{9}$

What about victims? The Women's Movement has taught us to be far more aware of the victimization of women, and there is a widespread sense that women are disproportionately victimized by violence. ${ }^{10}$ There is an important truth in that perception, but it is a complex truth. It is a truth that statistics seem to contradict.

The victims of reported crime are disproportionately male, again overwhelmingly so. Justice Department statistics indicate that compared to women, men are $123 \%$ more likely to be the victims of robbery and $161 \%$ more likely to be the victims of an aggravated assault. ${ }^{11}$

One's immediate reaction, given widespread perceptions of disproportionate victimization of women, is that statistics of this kind must be distorted, and in part this is true. The great majority of victims of domestic violence are female. ${ }^{12}$ Outside of prisons and other custodial institutions, over $90 \%$ of rape victims are

${ }^{9}$ See Bureau of Justice Statistics, U.S. Dep'T Of Justice, Report to the NATION ON CRIME AND JUSTICE 41 (2d ed. 1988) [hereinafter REPORT TO THE NATION].

${ }^{10}$ See S. REP. No. 197, 102d Cong., Ist Sess. 33 (1991) ("Women bear the disproportionate burden of some of the most pernicious crimes, like rape, and some of the most persistent crimes, like beatings in the home." ); S. REP. NO. 545, 101st Cong., 2d Sess. 30-31 (1990) (noting "a spiralling 'gender gap' of violence . . . [in which] female victimization is increasing faster than male victimization (at least for some crimes)" (citations omitted)).

"See Bureau of Justice Statistics, U.S. Dep't of Justice, Criminal VictimIZATION 1991, at 6 (1992) [hereinafter VICTIMIZATION IN 1991].

${ }^{12}$ In measuring domestic violence, a number of surveys suggest that male partners are victimized at about the same rate as female partners. See MURRAY A. STRAUS ET AL., BEHIND ClOSED DOORS: VIOLENCE IN THE AMERICAN FAMILY 266 (1980) (reporting a rate of 12.0 for husband-to-wife violence compared to a rate of 11.5 for wife-to-husband violence); Murray A. Straus \& Richard J. Gelles, Societal Change and Change in Family Violence from 1975 to 1985: As Revealed by Two National Surveys, 48 J. MARRIAGE \& FAM. 465, 470 (1986) (reporting that in 1985, the rate of husband-towife violence was 113 per 1000 couples, while the rate of wife-to-husband violence was 121 per 1000 couples). But the overall data on the rates of assault by victim gender present a misleading picture because the assaults experienced by male victims tend to be concentrated disproportionately in the milder forms of slapping or hitting; the female partners are much more likely to suffer the most serious assaults. See Irene $\mathrm{H}$. Frieze \& Angela Browne, Violence in Marriage, in FamiLy VIOLENCE 163, 181 (Michael Tonry \& Norval Morris eds., 1989) (noting that "the average number of severely violent assaults by a husband against a nonviolent wife was three times greater than the average number of wives' assaults on nonviolent husbands"). 
female. ${ }^{13}$ Yet rape and domestic violence are vastly underreported and underprosecuted. ${ }^{14}$

For other violent crimes, victimization rates are much higher for males than for females, and reporting problems cannot explain all of the difference. Household victimization surveys, a reasonably effective check on underreporting (except for domestic violence), show much higher victimization rates for men. ${ }^{15}$ In homicide, an offense for which victimization data are extremely reliable, we find that men and boys, $49 \%$ of the population, represent $74 \%$ of homicide victims. ${ }^{16}$ Over their lifetimes, men are about three times more likely than women to become the victims of homicide. ${ }^{17}$ For an African-American man, the chance of becoming a homicide victim is four-and-a-half times higher than for an AfricanAmerican woman, and sixteen times higher than for a white woman. ${ }^{18}$

Women's disproportionate victimization is nonetheless a reality, but it is a complex one, rooted not only in raw numbers but in judgments about the vulnerability of female victims and, perhaps,

${ }^{13}$ The Justice Department's household survey data indicate that only $8 \%$ of reported rape victims are male, but these data do not include the rapes (largely male) that occur in institutional settings, such as prisons. See BUREAU Of JUSTICE STATISTICS, U.S. DEP'T OF JUSTICE, HIGHLIGHTS FROM 20 YeARS OF SURVEYING CRIME VICTIMS 9 (1993). There are no reliable data on the incidence and prevalence of rape in prisons, but some studies, extrapolating from crude survey data, estimate that among inmates of prisons, jails, and juvenile "reform schools," there may be as many as 290,000 male rape victims per year. See Stephen Donaldson, The Rape Crisis Behind Bars, N.Y. TIMES, Dec. 29,1993 , at A11. That figure is more than double the Bureau of Justice Statistics' estimate for the number of female rape victims annually, although many believe that the number of female victims is much higher. See id. Inattention to sexual assault in prisons does not only harm the men who are its immediate victims; some observers believe that men and boys who are sexually victimized in custodial institutions are more likely to become rapists themselves when they are released. See id.

${ }^{14}$ See, e.g., S. REP. NO. 197, at 38 (noting that "[r]ape and domestic violence are some of the most underreported crimes in America"); S. REP. NO. 545, at 33 (noting witness testimony to the effect that "rape is still underreported and underprosecuted"); MARGARET T. GoRDON \& STEPHANIE RIGER, THE FEMALE FEAR: THE SOCIAL COST OF RAPE 34-37 (1991) (discussing the underreporting of rape).

${ }^{15}$ See Victimization in 1991, supra note 11, at 6 (finding 40.3 violent crimes against men per 1000 persons, but only 22.9 violent crimes against women per 1000 persons); REPORT TO THE NATION, supra note 9, at 27 (reporting that while men suffer assault at a rate of 32 per 1000 persons, women suffer assault at a rate of only 17 per 1000 persons).

${ }^{16}$ See REPORT TO THE NATION, supra note 9, at 28.

${ }^{17}$ See id.

${ }^{18}$ See id. 
an assumption of some contributory fault with regard to many of the victims on the male side: victims who provoked fights, assumed risks, or went looking for trouble. The victimization of women seems disproportionate not simply to women's share of the population but to their desert; the victimization of women seems particularly unfair. The proper complaint, therefore, is not that the victimization statistics lack "objectivity," because observations about women's disproportionate victimization involve an irreducible normative element. That perceptions about women's victimization rest in part on socially constructed value judgments does not, of course, render such perceptions invalid or unimportant.

What the data themselves suggest is that the criminal justice system's preoccupation with male offenders and male victims is not exclusively an artifact of cultural bias in reporting and charging behavior. In part, this preoccupation reflects the nature of the underlying phenomenon of crime in our society and probably most others. Nor would we expect (or want) progress for women to increase women's participation as offenders or as homicide, robbery, and assault victims. ${ }^{19}$ So for the foreseeable future, the raw material of criminal justice is likely to remain, to an overwhelming extent, disproportionately male in character.

Under these circumstances women have, until very recently, remained at the margins of thought about criminal justice problems. The criminal justice system has been run by men, against men, and for the benefit of men. Not so much different from the rest of society, but more so.

The Sections that follow consider some of what needs to be done to correct that imbalance in four areas of special concern to women-domestic violence, rape, sentencing, and prisons.

19 On the possibility that women's independence and increased workforce participation might increase women's rates of offending, see infra text accompanying notes 125-29. For a discussion of connections between women's independence and society's stereotypes of women as criminals, see Susan N. Herman, Thelma and Louise and Bonnie and Jean: Images of Women as Criminals, 2 S. CAL. REV. L. \& WOMEN's STUD. 53, 62 (1992); Elizabeth V. Spelman \& Martha Minow, Outlaw Women: An Essay on Thelma and Louise, 26 NEw ENG. L. REV. 1281, 1281 (1992). 


\section{DOMESTIC VIOLENCE}

Lack of attention to domestic violence has a venerable tradition in the criminal justice system. Failure to prosecute abusive husbands was not just the result of inattention, because for centuries, the criminal law gave the husband an affirmative privilege to beat his wife in order to provide her with what was seen as appropriate chastisement and instruction. ${ }^{20}$ The husband's formal privilege of chastisement was abolished by the end of the nineteenth century, ${ }^{21}$ but wife beating continued. The extent of it cannot be measured precisely, but even the cautious studies point to high levels of abuse: $28 \%$ of all women experiencing a violent assault at some point in their marriages; $16 \%$ of married women assaulted by a spouse in a single year. ${ }^{22}$

This culture of spousal abuse coexists with a police practice of not arresting wife beaters, especially in cases perceived as "ordinary" misdemeanor assaults. ${ }^{23}$ Many episodes of domestic violence involve life-threatening attacks, assaults with guns, knives, and other weapons, or brutal battering that leaves serious physical injuries. Police are likely to take such cases more seriously than the much

${ }^{20}$ See Anne M. Coughlin, Excusing Women, 82 CAL. L. REv. 1, 40-41 (1994) (noting that the husband's right to chastise his wife stemmed from "the belief that married women suffered from a volitional disability"); Joyce E. McConnell, Beyond Metaphor: Battered Women, Involuntary Servitude and the Thirteenth Amendment, 4 YALE J.L. \& FEMINISM 207, 232 (1992) (noting that “[t]he batterer's belief in a man's right to chastise his partner and to coerce sexual services remains entrenched in the law"). Blackstone attempted to rationalize the husband's privilege of chastisement by connecting it to the marital coercion doctrine, under which a husband could be liable for crimes the wife might commit in his presence (actual or constructive). It was only fitting, Blackstone argued, that the husband have a corresponding privilege of chastisement in order to deter his wife from actions that would expose him to criminal liability. See 1 WILLIAM BlaCkSTONE, COMMENTARIES 432 ("For, as he is to answer for her misbehaviour, the law thought it reasonable to intrust him with this power of restraining her, by domestic chastisement, in the same moderation that a man is allowed to correct his servants or children ...." ).

${ }^{21}$ See, e.g., Fulgham v. State, 46 Ala. 143, 143 (1871) (abolishing a husband's right to chastise his wife); The Queen v. Jackson, 1 Q.B. 671, 681-82 (1891) (abolishing the right of marital chastisement in England); see also Bernadette D. Sewell, Note, History of Abuse: Societal, Judicial, and Legislative Responses to the Problem of Wife Beating, 23 SUFFOLK U. L. REV. 983, 984 (1989) (noting that legal authorization of marital chastisement "continued to exist in many Western cultures until the late nineteenth century").

22 See Frieze \& Browne, supra note 12, at 179.

23 See LAWRENCE W. SHERMAN, POLICING DOMESTIC VIOLENCE: EXPERIMENTS AND DILEMMAS 26-27 (1992) (describing patterns of underenforcement of domestic violence laws). 
more numerous domestic disturbances classified as misdemeanorsthose involving loud arguments, slapping, shoving, and kicking. ${ }^{24}$ Arrest rates in spousal abuse cases range from a low of only $12 \%$ to a high of no more than $50 \% .^{25} \mathrm{Up}_{\mathrm{p}}$ through the $1970 \mathrm{~s}$, police training materials instructed officers to avoid making an arrest whenever possible, ${ }^{26}$ and in several states, the majority of police departments had explicit policies against making arrests in domestic assault cases. ${ }^{27}$

Advocates for battered women brought a number of lawsuits challenging these practices on sex discrimination grounds. ${ }^{28}$ There is, however, a problem in trying to attack police practices in this way: arrest rates are very low in all kinds of assault cases, even those involving assailants who are strangers to the victim. ${ }^{29}$ Yet the woman who is repeatedly abused by her partner probably needs police protection much more than a man who gets into a fight in a bar. So lawyers working for battered women shifted their focus from one of trying to eliminate sex discrimination to one of trying to eliminate discretion. Mandatory arrest is now the solution favored by many leading advocates for battered women. ${ }^{30}$

${ }^{24}$ See id. at 26 (noting that police widely ignore domestic violence that involves only slaps and kicks).

${ }^{25}$ See Delbert S. Elliott, Criminal Justice Procedures in Family Violence Crimes, in FAMILY VIOLENCE, supra note 12 , at $427,438$.

${ }^{26}$ See Roger LANGley \& Richard C. LeVY, Wife Beating: The Silent Crisis 164-65 (1977) (citing the Detroit Police Department's General Orders which imply that domestic violence is not a crime); Elliott, supra note 25, at 435 (noting that "[t]here is little question that the. . . 'hands off' view predominated prior to the early $1970 s^{\prime \prime}$ and that "[p]olice training materials clearly specified that, when responding to domestic disputes, arrest was to be avoided whenever possible").

${ }^{27}$ See Lawrence W. Sherman \& Richard A. Berk, The Minneapolis Domestic Violence Experiment, POLICE FOUND. REP., Apr. 1984, at 7, 8.

${ }^{28}$ See, e.g., Thurman v. City of Torrington, 595 F. Supp. 1521, 1531 (D. Conn. 1984) (denying the defendant's motion to dismiss a Fourteenth Amendment claim that police provided less protection to women abused by spouses or boyfriends than to victims of nondomestic violence); Bruno v. Codd, 396 N.Y.S.2d 974, 979 (Sup. Ct. 1977) (denying a police department's motion for summary judgment on charges of inadequately protecting women from their abusive husbands), rev'd, 407 N.Y.S.2d 165 (App. Div. 1978) (mem.), and affd, 393 N.E.2d 976 (N.Y. 1979); see also Joan Zorza, The Criminal Law of Misdemeanor Domestic Violence, 1970-1990, 83 J. CRIM. L. \& CRIMINOLOGY 46, 53-60 (1992) (documenting the history of sex discrimination in suits filed against violent husbands).

${ }^{29}$ See Elliott, supra note 25 , at 438-41 (examining the similarity between arrest rates for assaults committed against family members and for similar violent crimes perpetuated against strangers).

${ }^{30}$ See, e.g., Clifford Krauss, Keeping in Touch with the Victims of Domestic Violence, N.Y. TIMES, Nov. 21, 1994, at B3 (noting victims' advocates' praise for mandatory 


\section{A. Mandatory Arrest Through the Lens of Feminist Jurisprudence}

Domestic violence, a central issue in the struggle to assure dignity and equality for women, is extensively discussed in feminist literature. ${ }^{31}$ Yet there has been little effort to consider how battles over theoretical commitments or attempts to refine theoretical paradigms might inform efforts to begin solving this critical problem.

One obvious irony involves the manner in which the tactic favored by many feminist reformers (mandatory arrest) collides with the part of feminist theory that advocates open-textured standards and attention to the nuances of relationships. Feminists inspired by the work of Carol Gilligan ${ }^{32}$ reject inflexible rights as a distinctively male conception. ${ }^{33}$ Police officers who do not arrest battering husbands are not being very "male" in that sense. They are making ad hoc judgments, based on their intuitions about the whole situation.

This sort of police discretion is presumably not what Gilligan really meant by an ethic of care and connection. Nevertheless, the example highlights a more general point about the supposed clash between a male ethic of rights and a female ethic of context and relationship. There is nothing especially feminist about an ad hoc, discretionary approach to making decisions. It all depends on the values that inform the exercise of the discretion. Nor should we automatically count as "feminist" any ethic that emphasizes caring, connection, and the continuity of relationships. There are situations where that ethic is not only out of place, but dangerous to women. ${ }^{34}$ Everything depends on the particular problem, the

arrest policies instituted in New York City).

${ }^{31}$ For references to the recent literature, see SANFORD H. KADISH \& STEPHEN J. SCHULHOFER, CRIMINAL LAW AND ITS Processes 829 \& n.2 (6th ed. 1995).

${ }^{32}$ See, e.g., GILLIGAN, supra note 4.

"ss See, e.g., M. Kay Harris, Moving into the New Millennium: Toward a Feminist Vision of Justice, PrisoN ]., Fall-Winter 1987, at 27, 32 ("[In Gilligan's research] [m]en were more likely to employ a 'rights/justice' orientation [toward moral issues] and women were more likely to reflect a 'care/response' orientation ....."); Frances Heidensohn, Models of Justice: Portia or Persephone? Some Thoughts on Equality, Faimess and Gender in the Field of Criminal Justice, 14 INT'L J. Soc. L. 287, 295-96 (1986) (noting that men become "detached, autonomous and individualized" in their quest for justice, while women tend to focus on context and caring).

"An "ethic of care" poses related dangers in such criminal justice contexts as the juvenile court movement, civil commitment of the mentally ill, and rehabilitative models of sentencing. See Stephen J. Schulhofer, The Gender Question in Criminal Law, SOC. PHIL. \& POL'Y, Spring 1990, at 105, 124. In particular, 
values presupposed, and the kinds of people who will make the judgments. As Kathleen Daly observes:

When court officials define crime and impose sanctions, they use relational reasoning and an ethic of care toward defendants .... This female voice may not contain the same relational concerns that women (or feminists) desire, but that is different from saying that men's form of legal reasoning does not contain relational, caretaking, or responsibility concerns. Thus, the problem in criminal-court practices is not that the female voice is absent, but that certain relations are presupposed, maintained, and reproduced. ${ }^{35}$

Scholars associated with what is often called "radical feminism" approach this problem from the opposite direction. They argue that women should have an absolute right to bodily integrity and protection from aggression. ${ }^{36}$ Formal equality (a "liberal feminist" stance) is a poor benchmark here because men involved in fights and minor assaults do not have the same need for state protection from one another that women have for protection from assaultive men. Thus, even if the police are equally inattentive to acquaintance assaults when victims are men or women, the state's seemingly even-handed inaction is nonetheless an affirmative policy that contributes to the subordination of women. ${ }^{37}$ For feminists committed to this view, society has an obligation to use arrest powers vigorously when a man violates a woman's right to physical safety. ${ }^{38}$ This is a coherent perspective, and surely an appealing

the model of caring and connection [is flawed] because ... conflicting interests are inherent in any criminal justice system that serves society's interests in deterrence and social protection. A system of criminal law premised on caring and connection will simply mask conflict and invite the abuses that vague standards of intervention have produced over and over in ostensibly benign programs.

Id. (citation omitted).

${ }^{35}$ Kathleen Daly, Criminal Justice Ideologies and Practices in Different Voices: Some Feminist Questions About Justice, 17 INT'L J. Soc. L. 1, 2 (1989).

${ }^{36}$ See, e.g., MACKINNON, supra note 3, at 41 (noting that in domestic relationships, battery of women tends to be ignored, whereas "[w] hen [men] are hit, a person has been assaulted").

${ }^{37}$ See id. at 76 (arguing that when government refuses to prosecute for marital rape, "the woman's obligation to deliver sexually is effectively enforced by the state").

${ }^{38}$ See Kathleen Waits, The Criminal Justice System's Response to Battering: Understanding the Problem, Forging the Solutions, in FEMINIST JURISPRUDENCE 188, 202 (Patricia Smith ed., 1993) (arguing that "[a]rrest of the batterer is the central element of an effective police response"); Zorza, supra note 28, at 66 (arguing that in order to deter batterers effectively, more severe sanctions should be imposed). 
one, but it takes no account of the psychological, social, and institutional dynamics that determine whether, and under what conditions, a "get tough" approach will really help a particular victim or women in general.

\section{B. Evaluating Mandatory Arrest}

Good policy for domestic violence cases depends less on the theoretical appeal of either "absolute rights" or "relational reasoning" than on the actual effect of laws and policies that translate these conceptions into operational strategies. In Minneapolis, police conducted an experiment to determine the effect of arrest in misdemeanor assault cases. ${ }^{39}$ The result was dramatic support for mandatory arrest: by every measure, arrest was reported to be more effective than other responses such as counseling the parties or sending the suspect away. ${ }^{40}$ The results were widely reported and enthusiastically received; numerous police departments adopted rules requiring arrest in domestic assault cases, and more than a dozen states enacted statutes mandating that approach statewide. ${ }^{41}$ By 1989 , only five years after the study results were released, $84 \%$ of urban police agencies reported having mandatory or preferred arrest policies for domestic violence cases. ${ }^{42}$

Unfortunately, the rapid and uncritical acceptance of the Minneapolis findings was premature because flaws in the study made it hard to be sure that reported deterrent effects of arrest were not spurious. ${ }^{43}$ To afford a more complete picture, experi-

${ }^{39}$ See Lawrence W. Sherman \& Richard A. Berk, The Specific Deterrent Effects of Arrest for Domestic Assault, 49 AM. Soc. REv. 261, 262 (1984) (reporting the results of the Minneapolis study).

${ }^{40}$ See Sherman \& Berk, supra note 27, at 7. For an example of early warnings about possible flaws in the Minneapolis study and the need for caution in interpreting its findings, see Elliott, supra note 25, at 453-54.

${ }^{41}$ See Lawrence W. Sherman \& Ellen G. Cohn, The Impact of Research on Legal Policy: The Minneapolis Domestic Violence Experiment, 23 L.' \& Soc'Y REV. 117, 129 (1989) (noting that "[ $t]$ he publicity about the Minneapolis experiment did reach a large number of police departments and may have had a substantial . . . influence on policy"); Zorza, supra note 28, at 64-65 nn.182-86 (citing to the applicable state statutes).

${ }^{42}$ See Lawrence W. Sherman, The Influence of Criminology on Criminal Law: Evaluating Arrests for Misdemeanor Domestic Violence, 83 J. CRIM. L. \& CRIMINOLOGY 1, 23-24 (1992).

${ }^{43}$ Some of the deterrence effects were inferred from official arrest records, but such records cannot reveal whether arrest is deterring subsequent violence or only subsequent reports. The Minneapolis study attempted to control for this problem through follow-up interviews with victims, but there was a large falloff in victim 
ments testing the effects of mandatory arrest were repeated, among broader demographic groups and with better data-collection procedures, in five other cities. ${ }^{44}$ In three of them, arrest had a greater deterrent effect than other responses only in the short run; the effect tended to diminish over time, and within a year after the initial intervention, suspects who had been arrested were more likely to engage in repeat violence than those who had merely been warned. ${ }^{45}$ A reanalysis of the Minneapolis data revealed a similar pattern in that city. ${ }^{46}$ Over time, in other words, arrest often seems to have an "escalation effect," aggravating the subsequent violence.

Advocates for battered women have attacked these more recent studies, especially the "do nothing" strategy they seem to support. As one attorney writes, "We do not consider eliminating arrest for ... [robbery], [just] because it may not deter a particular... class of individuals. "47 Unfortunately, that is a dangerous answer. The objective here is to protect battered women. If arrest is not doing that, we need to consider using other solutions, either in conjunction with arrest or as an alternative to it. Moreover, the danger is not just that arrest may not deter, but that in some situations, arrest may make matters worse. Mandatory arrest may cause more violence to the very women we are trying to help.

Other unintended harms to women have emerged as well. In mandatory arrest jurisdictions, police are sometimes obliged to arrest the abused woman because her partner alleges that she had hit

participation in the follow-ups, and the follow-up study was limited to only six months, a period when temporary deterrence effects may dominate to the extent that court proceedings remain possible. See Elliott, supra note 25, at 453 (noting that only $49 \%$ of the victims in the Minneapolis study completed all 12 follow-up interviews).

- 'See SHERMaN, supra note 23, at 15-18 (reporting results from similar experiments conducted in Omaha, Charlotte, Milwaukee, Colorado Springs, and Miami).

${ }^{45}$ See id. at 17, 188-87 (describing an initial deterrent effect of arrest, followed by a subsequent escalation in the likelihood of repeat violence in Omaha, Charlotte, and Milwaukee).

${ }^{46}$ In Minneapolis, the deterrent effects of arrest (measured by victim interviews) decayed over time and disappeared after six months. See id. at 197. Although the Minneapolis study did not collect victim interview data after six months, the trend of the data suggests the possibility of an escalation effect after the six-month point. (When repeat violence was measured by official arrest records, arrest had a clear deterrent effect that continued for the entire 18-month period studied. See id. But official records may present a misleading picture of the actual level of battering, if arrest deters victims from reporting subsequent incidents to the police.)

${ }^{47}$ Zorza, supra note 28 , at 66 . 
him. ${ }^{48}$ And there is some indication that visible, highly popular mandatory arrest programs have permitted legislators to reduce their support for more costly solutions like shelters for battered women. ${ }^{49}$

Surprisingly, the tentative Minneapolis study and its recommendations for a more punitive approach received widespread attention and an immediately favorable reception, but public officials and the media have either attacked or ignored the more thorough studies that suggest the opposite conclusion. ${ }^{50}$ Theoretical and ideological commitments to punitive strategies and to a rights-oriented response to aggression seem to dominate any concern for designing operational programs which actually help abused women. Yet the best available evidence suggests that an across-the-board policy of mandatory arrest should be anathema to feminists. As Lawrence Sherman writes, using mandatory arrest to fight domestic violence "may make as much sense as fighting fire with gasoline. ${ }^{n 1}$

\section{Selective Mandatory Arrest?}

An important qualification to this pessimistic assessment of mandatory arrest emerges when data from the follow-up studies are disaggregated. The escalation effect seems especially strong when the batterer is unemployed, but arrest does appear to have a net deterrent effect when the husband has a job or other marks of social stability. ${ }^{52}$ That finding triggers a further series of dilemmas. Should we arrest only the employed? If not, should we arrest in all cases, knowing that this will harm some women? A third possibility is to leave the decision to each officer on the spot. That would probably give us the worst of both worlds: police would arrest blacks and the underclass while letting off middle-class white

${ }^{18}$ In Connecticut, mandatory arrest policies reportedly led to the arrest of both spouses in $14 \%$ of the cases. See Jan Hoffman, When Men Hit Women, N.Y. TIMES, Feb. 16, 1992, (Magazine), at 23, 26. Moreover, if children are present and no other caretaker for them is available, the children may have to be placed in state custody until one of the parents is released. See id.

49 See SHERMAN, supra note 23, at 255.

${ }^{50}$ See id. at 135-36 (describing political attacks on empirical research and the unwillingness of the Wisconsin legislature to repeal its mandatory arrest statute after the Milwaukee study had indicated the harmful effects of that policy); id. at 266 (describing sparse press coverage of the Milwaukee findings); Sherman \& Cohn, supra note 41 , at 129 (stating that publicity about the Minneapolis study reached a large number of police departments and had a substantial influence on policy).

${ }^{51}$ SHERMAN, supra note 23, at 210.

${ }^{52}$ See id. at 155 . 
offenders with a warning. ${ }^{53}$ In practice we would get warnings when arrest might really help and arrest when it is most likely to be counterproductive.

A final possibility is to leave the choice up to the victim. ${ }^{54}$ This seems a promising option, but it too conceals dilemmas and risks. Victims know the offender better than the police do and may be able to predict whether his arrest will be an effective deterrent. Deference to the victim's wishes also may strengthen her self-esteem and empower her within the relationship. Yet there are important countervailing concerns. Few victims will be aware of the long-run escalation effects of arrest or of the complex roots of that phenomenon. Moreover, the victim will have to make her decision at a moment of great stress with little relevant information and little time for reflection. ${ }^{55}$ Even if the police talk privately to the victim in a separate room, the offender may perceive that her preferences control the arrest decision, and if so, the escalation effects of arrest could be aggravated. Deference to the victim could backfire in another way if victims who fear retaliation are deterred from expressing their preference for arrest.

The effects of deferring to the victim's preferences are worth studying carefully, but there is little reason to hope that such a policy will offer a panacea for the dilemmas we have been considering. In any case, to underscore the obvious, theoretical conceptions of domination and related commitments to "empowering the victim ${ }^{\text {n56 }}$ provide little practical guidance to those who want to find a way to help women caught in abusive relationships. The value of deference to victim preferences turns on the specific methods used to make that policy operational and on the complex, multidirectional effects that those methods will have in practice.

${ }^{33}$ See, e.g., Caroline Forell, Stopping the Violence: Mandatory Arrest and Police Tort Liability for Failure to Assist Battered Women, 6 BERKELEY WOMEN's L.J. 215, 221 (1991) (summarizing results of a Duluth study in which minority males comprised $8.5 \%$ of those arrested under a policy of mandatory arrest, but comprised $33 \%$ of arrestees when the decision to arrest was left to police officers' discretion).

${ }^{5+}$ See, e.g., David A. Ford, Prosecution as a Victim Power Resource: A Note on Empowering Women in Violent Conjugal Relationships, 25 L. \& Soc'Y REV. 313, 330 (1991) (evaluating deference to victim preferences in deciding whether to arrest and prosecute batterers).

${ }^{55}$ To make matters worse, a significant number of domestic violence victims (21\% in one city studied) are intoxicated at the time police arrive on the scene. See SHERMAN, supra note 23, at 207.

${ }^{56}$ See Ford, supra note 54, at $317-20$ (discussing empowerment theories). 


\section{Getting Tougher: Giving Content to "Arrest"}

Instead of seeking to minimize arrest, especially for unemployed husbands, a more promising approach might be to consider more severe sanctions for all categories of offenders. Indeed, mandatory arrest may appear ineffective or dangerous in part because the response being advocated ("arrest") is mainly a slogan, not a fully specified policy. In many cities, suspects arrested on domestic violence charges are free within a few hours; among the six cities in which mandatory arrest experiments were conducted, average times in custody varied from twenty-four hours to only two. ${ }^{37}$

The constitutional right to bail ${ }^{58}$ accounts for some of the rapid release times and may make that feature of the current landscape difficult to change. Nonetheless, rapid release times probably are not a major cause of the ineffectiveness of mandatory arrest, because most of the experiments show some deterrence over the short run, even when suspects spent very little time in jail. ${ }^{59}$ The problem is that the deterrence effect of arrest tends to dissipate, and escalation effects begin to dominate, roughly six months after the arrest. ${ }^{60}$ The decay of deterrence effects could be slowed by making the initial arrest a more unpleasant experience, but that approach obviously risks making the escalation effects more severe as well.

There is another reason why mandatory arrest is primarily a slogan, not a concrete policy. To advocate "arrest" says nothing about what should happen after the arrestee's inevitable release on recognizance or money bail. Husbands arrested for misdemeanor assault are almost never prosecuted. ${ }^{61}$ An obvious option is to combine the increased use of arrest with a greater determination to get convictions and jail time. But the available data permit little confidence that prosecution provides the easy answer. In Milwaukee and Charlotte, two cities in which mandatory arrest appeared to produce an escalation effect, the percentage of suspects prosecuted

${ }^{57}$ See SHerman, supra note 23 , at 140-42. Longer times in custody did not correlate cleanly with either the deterrence effects or the escalation effects, perhaps because times were poorly measured, and other factors that affect the severity of the arrest experience (jail conditions, for example) were not measured at all. See id.

${ }^{58}$ See U.S. CONST, amend. VIII.

${ }^{59}$ See SHERMAN, supra note 23, at 129, 141.

${ }^{60}$ See id. at 189.

${ }^{61}$ See Sherman, supra note 42, at 29 (reporting that in Minneapolis, only $4 \%$ of those arrested were ever convicted, and in Milwaukee, only $1 \%$ were ever convicted). 
and convicted was only $1 \%$ and $28 \%$ respectively. ${ }^{62}$ But substantial escalation effects also occurred in Omaha, a city where $64 \%$ of the arrestees were prosecuted and convicted. ${ }^{63}$

Normatively, as well, the increased-prosecution approach poses uncomfortable choices. Since employed offenders seem to be deterred by arrest alone, ${ }^{64}$ do we reserve prosecution and jail time for the unemployed? That's not easy to live with. Or do we jail all the offenders? If so, the men who had jobs often will lose them, and middle-class wives who have sought help in the past may now be afraid to call the police. And no matter which way we resolve these issues, we still cannot be sure that a more punitive approach will have a net deterrent effect overall. For the chronic, seriously violent batterer, vigorous prosecution and substantial prison time are usually appropriate. But unless we are willing to treat every episode of domestic assault as a felony deserving a year or more in prison, the deterrent and incapacitative effects of punishment, in cases not involving a weapon or serious bodily injury, are inherently limited.

\section{E. Other Alternatives}

Because mandatory arrest and other punitive responses have such problematic effects, other options need to be explored. Yet the array of promising alternatives is meager.

One seemingly constructive approach is for the officer on the scene to refer the abuser to counseling services, possibly with the added inducement of a court order or a threat to arrest after any repeat episode. Unfortunately, evaluations of this option are just as pessimistic as those concerning the use of arrest. There is as yet no evidence that counseling reduces the offender's propensity for repeat violence. ${ }^{65}$ What is worse, because women are more likely to remain with an abuser who is in counseling, the likelihood of further victimization actually increases when the counseling option is used. ${ }^{66}$ Thus, counseling, like mandatory arrest, actually seems

62 See SHERMAN, supra note 23, at 141-42.

6s See id.; Franklyn W. Dunford et al., The Role of Arrest in Domestic Assault: The Omaha Police Experiment, 28 CRIMINOLOcY 183, 193 (1990).

64 See supra text accompanying note 52.

${ }^{65}$ See SHERMAN, supra note 23, at 249 (noting that "no randomized experiment yet demonstrat[es] that court-ordered counseling can reduce the frequency or prevalence of repeat domestic violence"); Zorza, supra note 28 , at 67 (noting that "completing batterer treatment made no difference in stopping future violence").

${ }^{66}$ See Zorza, supra note 28 , at 67 (suggesting that victims may be "deceived" into 
associated with an escalation effect. Such findings obviously do not mean that counseling cannot be helpful. Outcomes may depend on the structure and quality of the counseling programs, the kinds of offenders who participate in them, the degree to which participation is coerced, and so on. Well-conceived programs certainly deserve to be funded, tried, and tested, but until that can be done, the counseling option needs to be viewed with caution.

Orders of protection can backfire in a similar way. As a popular component of domestic violence reform legislation, orders of protection have proved notoriously ineffective, largely because statutory mandates and newly created rights have not been accompanied by commensurate efforts to provide necessary resources or to educate police, court officials, and victims in the proper use of new procedures. ${ }^{67}$ As a result, such orders may serve only to foster misplaced confidence that ultimately leaves victims at greater risk. ${ }^{68}$ Except in the case of the most determined aggressors, orders of protection probably can contribute to the protection of abused women, provided they are backed by thorough training and better resources. In the absence of substantial and sustained institutional support, however, they risk causing more harm than good.

Another important approach is to expand the availability of shelters for battered women, so that victims can more easily leave abusive relationships. Police called to the scene of a domestic assault could be required to explain that option and to offer to transport the victim directly to a shelter if she wishes. Lawrence Sherman suggests this approach as a possible way for police to protect the victim against both the long-run escalation effects of arresting the abuser and the short-run dangers of leaving the scene without arresting him. ${ }^{69}$

Theoretical commitments and intuitions of fairness prompt resistance to this approach, however. Why should the victim be the

reconciling with abusers in counseling because the victims may think that counseling will produce an end to the violent behavior).

${ }^{67}$ A study by the National Institute of Justice found that police often fail to inform victims of available remedies, fail to serve the orders of protection on the abuser (thus nullifying their effect), and fail to arrest when orders of protection are violated. See Peter Finn, Civil Protection Orders: A Flawed Opportunity for Intervention, in WOMAN BATTERING: POLICY RESPONSES 155, 182 (Michael Steinman ed., 1991).

${ }^{68}$ See Janice Grau et al., Restraining Orders for Battered Women: Issues of Access and Efficacy, WOMEN \& POL., Fall 1984, at 13, 27 (calling for improvement of the procedures for obtaining, and enforcing, restraining orders).

${ }^{69}$ See SHERMAN, supra note 23, at 208-10. 
one who has to leave her home? Why not require the abuser to leave? Of course, the victim still can reject the offer; she could not be required to leave. But when a police officer refuses to arrest the abuser and encourages the victim to accept transportation to a shelter, we can hardly view state policy as simply facilitating the exercise of a wholly "voluntary" choice.

The Minneapolis experiment tested the option of requiring the abuser to leave the premises (ostensibly for eight hours) without arresting him. ${ }^{70}$ In reality, however, the abuser was free to return as soon as the police left. Only arrest or an order of protection will keep the abuser out of the home, but these responses can be ineffective and dangerous, as we have seen. In any case, the Minneapolis experiment showed that requiring the abuser merely to leave produced high rates of repeat violence. ${ }^{71}$ Against that background, the fact that the victim has a right to remain on the premises, while the abuser has none, can be dispositive only as a matter of pure theory. When a terrorist is spraying the street with bullets, those of us who have the right to remain on the sidewalk may prefer not to stand our ground. In an imperfect world, discretion may be the better part of valor. And the world of efforts to control domestic violence is hedged by imperfections at every turn.

\section{F. Developing Effective Responses}

The preceding considerations suggest that sharply etched, theoretically satisfying positions are unlikely to carry us very far toward effective solutions to the problem of domestic violence. Helpful responses are more likely to be complex, eclectic, costly, and elusive.

Several components of a constructive policy nonetheless can be identified. First, complex and contingent response strategies must not obscure the message that spousal abuse is a crime and that it will not be tolerated. Every police response must be structured to send the offender a clear warning that domestic violence is unacceptable and that future incidents will be met with increasingly punitive responses. Similarly, to combat any police tendency to take domestic violence cases cavalierly, officers need guidelines that require an energetic response. Mandatory arrest serves that function but only

${ }^{70}$ See Sherman \& Berk, supra note 27, at 7, 9.

"See id. at 7, 12. 
at some risk to the women we are trying to help. A more useful rule of thumb, therefore, would not insist on arrest per se, but mandatory action-action of some sort, from a list of strong, constructive alternatives, ${ }^{72}$ and a mandatory report (normally in writing), both to ensure a thoughtful response and to inform officers who might be called to the same address in the future.

Specific response options will necessarily reflect the services and programs (including prosecution programs) available in the particular jurisdiction; over the longer run, effort should focus on strengthening and evaluating alternative approaches. For chronic offenders and cases involving serious injuries, a vigorous prosecution program should assure substantial jail or prison terms. In the most minor cases, a stern warning or a reference to counseling may be appropriate, especially if records are adequate to assure that there have been no prior episodes of violence involving the same couple. For cases falling in between these extremes, arrest or some other means of separating the parties should be considered, with choices depending on the woman's desire to preserve the relationship, the history of past abuse, and other relevant circumstances. Where resources and back-up procedures permit, it may be appropriate to require the husband to leave and stay away long enough for the wife to obtain an effective order of protection. But if that avenue seems unlikely to afford real safety for the woman, an offer to transport her to a shelter may be appropriate, if that is the course she prefers.

The spousal-abuse problem illustrates two general points that apply to criminal justice and to probably most other areas of the legal system. First, legal, social, and institutional details are critical. Second, quick-fix statutes and doctrinal change do very little, and may even backfire, unless they are backed by changes in attitudes, personnel, and resources.

\section{RAPE}

I have just suggested that rigid rules will not work well in domestic violence cases. There, we need to rely on flexible standards. For rape statutes, I reach the opposite conclusion.

${ }^{72}$ See SHERMAN, supra note 23, at 253-56 (listing options including transporting the victim to a shelter, taking the suspect or victim to a detoxification treatment center, and allowing the victim to decide if an immediate arrest should be made). 
At one time, the law of rape openly denied equality to women, for example, in rules that required special corroboration for rape complaints. ${ }^{73}$ Formal inequalities have largely disappeared, but the problems have not. Most of the problems stem from the highly contextual way that the formally equal doctrines of rape law are applied in practice. As in the case of arrests for domestic violence, the law is quite preoccupied with the nuances of the relationship between the alleged offender and the victim. What is missing is not a jurisprudence of context. What is missing is sufficient respect for what should be clear-cut rights.

Because the current feminist critiques are by now familiar, I will sketch the problems and the prevalent criticisms rather quickly. Then I will suggest a perspective that is a bit different from the ones most often discussed.

\section{A. The Prevailing Law of Rape}

The controversies are framed by a definition of rape that has been with us since the time of Blackstone-intercourse by force and without consent. ${ }^{74}$ There have been two important waves of statutory reforms, the Model Penal Code revision in the 1950s and revisions inspired by feminist reformers in the $1970 \mathrm{~s}^{75}$ New statutes relaxed the rules of evidence and tinkered with the definitions of force and consent. But all of the statutes accepted the basic framework, which still requires both force and nonconsent. ${ }^{76}$

${ }^{75}$ See, e.g., United States v. Wiley, 492 F.2d 547, 550-51 (D.C. Cir. 1973) (establishing that a person may not be convicted of a "sex offense" unless the testimony of the victim is corroborated by, for example, medical evidence); see also Note, The Rape Corroboration Requirement: Repeal Not Reform, 81 YALE L.J. 1365, 136672 (1972) (recounting the history and status of the corroboration requirement). Wiley was overruled by United States v. Sheppard, 569 F.2d 114, 117 (D.C. Cir. 1977) (holding that corroboration of the victim's testimony is no longer a requirement for conviction in a sex offense case). Nearly all American jurisdictions have abandoned special corroboration rules applicable only to rape complaints. See KADISH \& SCHULHOFER, supra note 31, at 371 (noting that no American state now requires corroboration in forcible rape cases).

74 See 4 WILLIAM BLACKSTONE, COMMENTARIES 210 (defining rape as "carnal knowledge of a woman forcibly and against her will").

${ }^{75}$ For a discussion of the background and specific elements of the reforms of the 1950s and the 1970s, see Stephen J. Schulhofer, Taking Sexual Autonomy Seriously: Rape Law and Beyond, 11 L. \& PHIL. 35, 36-40 (1992).

${ }^{76}$ See id. at 38-39. 
The reforms of the 1970s made convictions somewhat easier, but important kinds of abuse still are not covered by statutory language. Two examples from recent cases will serve to illustrate my points.

1. The defendant meets the victim in a singles bar, and she gives him a ride home. When they get there, she turns down his invitation to come inside, but he is not about to take "no" for an answer. He takes her car keys from the ignition and pleads with her to come in for a few minutes. It is 1:00 a.m., in an unfamiliar neighborhood, and she is frightened, so she goes with him under protest. In his room, he presses her for sex. She keeps saying "no" and starts to cry, but she eventually submits so that he will let her leave. ${ }^{77}$

The appellate court said it would uphold the rape conviction in this case, but only because there was evidence that the defendant had threatened the victim with direct physical harm. ${ }^{78}$ Why should that detail be critical to the result?

2. The defendant and the victim live together for several months. He often beats her to make her meet his sexual demands. Eventually, she moves out, but one day they meet again and go to a friend's house to talk. The defendant bluntly announces that he wants sex, but she refuses. He orders her to lie down on a bed. She freezes in fear, while he undresses her and penetrates her. ${ }^{79}$

Should that kind of behavior be sufficient to make out a case of rape? The North Carolina Supreme Court said the evidence of nonconsent was overwhelming. But it also said there was no proof that the defendant had used force. So it reversed the conviction. ${ }^{80}$

These are situations where the defendant's behavior is egregiously wrong, by any standard of common decency. But existing conceptions of force and nonconsent are not clear enough to make the conduct illegal.

\section{B. Strategies for Reform}

Most reformers responding to problems such as those described above make essentially two points: 1) "no" means no, ${ }^{81}$ and 2) force should extend from explicit to implicit threats, from

\footnotetext{
77 See State v. Rusk, 424 A.2d 720 (Md. 1981).

${ }^{78} \mathrm{See}$ id. at 728.

${ }^{79}$ See State v. Alston, 312 S.E.2d 470 (N.C. 1984).

${ }^{80}$ See id. at 475-76.

${ }^{81}$ See, e.g., ESTRICH, supra note 7, at 102 (maintaining that the law should define "consent" in such a way that "no" means no).
} 
violence to implicit power. ${ }^{82}$ These points are plausible, and they are certainly widely accepted. But on close inspection, these solutions turn out to be misdirected.

\section{1. "No" Means No}

It is hard to see why the claim that "no" means no should be considered a revolutionary idea, but many people are still hotly debating it. In a recent article, Professors Husak and Thomas marshalled social science surveys in which many women say that, for them, "no" does not mean no. ${ }^{83}$ The authors conclude that contemporary American culture does not give a verbal "no" the meaning of unequivocal nonconsent that $I$ and others have attributed to it. They write that "Schulhofer's proposal [to treat a verbal "no" as sufficient to establish nonconsent] is not without cost to women [because] it distorts rather than accurately represents [existing social] convention[s] . . ." 84

These objections to treating "no" as unequivocal evidence of nonconsent reflect conceptual, as well as political, disagreement. "No" means no is in part a cultural claim and an advocacy slogan; as such it invites skeptics to question what "no" really does mean. The usual feminist response to such skeptics has been to reassert forcefully that "no" does mean no and that any non-Neanderthal male should agree. ${ }^{85}$ It is not surprising that feminists would be reluctant to concede that "no" might ever mean yes (apart from cases of abject false consciousness). Yet much of this debate results from misunderstanding the significance of empirical data for what is ultimately not an empirical issue. For law, the relevant question

${ }^{82}$ See, e.g., Susan Estrich, Rape, 95 YALE L.J. 1087, 1115 (1986) (arguing that courts should "understand force as the power one need not use (at least physically)").

${ }^{83}$ See Douglas N. Husak \& George C. Thomas III, Date Rape, Social Convention, and Reasonable Mistakes, 11 L. \& PHIL. 95, 122 (1992). In a recent survey of Texas female undergraduates, $39.3 \%$ reported that they had said "no" when they meant yes, and $60.8 \%$ of the sexually experienced women in the survey said that they had done so. See Charlene L. Muehlenhard \& Lisa C. Hollabaugh, Do Women Sometimes Say No When They Mean Yes? The Prevalence and Correlates of Women's Token Resistance to Sex, $54 \mathrm{~J}$. PERSONALITY \& SOC. PSYCHOL. 872, 874 (1988). The authors are quick to point out that this pattern of communication, although rational for some women, can teach men to disregard women's refusals and thereby increase the incidence of rape. See id. at 878.

${ }^{84}$ Husak \& Thomas, supra note 83, at 113.

85 See, e.g., CATHarine A. MACKInNON, TOWARD a FEMINIST Theory of the STATE 175 (1989) ("If rape laws existed to enforce women's control over access to their sexuality, ... no would mean no .... . ). 
is the effect that should be attributed to a woman's use of the word "no."

Although not decisive, the empirical landscape is obviously relevant here, because in an inquiry about what people mean when they speak, no one would want to give a word a meaning for legal purposes that is utterly at odds with ordinary usage. But the matter becomes a legal issue precisely because the usage of the word is not uniform throughout the culture. It can hardly be fatal to the feminist position, therefore, to discover that women who say "no" do not always mean the same thing. Because they do not, mistakes are possible. And so long as neither law nor culture develops rules to permit uniform appraisal of such mistakes, some of them can plausibly be described (although this will pain many feminists) as reasonable. The proposition that, for legal purposes, "no" means no is, therefore, primarily a normative claim about how the word should be understood in the face of ambiguity about its actual meaning in any given context.

The objection that taking "no" to mean no will make it "harder for some women to get what they want ${ }^{866}$ therefore misses the point of such a proposal. As with any default rule, the legal proposition that "no" means no does not claim infallible accuracy; to the contrary, the absence of empirical consensus is its raison d'etre. It presupposes ambiguity and seeks to allocate the risk of the inevitable misunderstandings.

As a normative claim, the proposition that "no" should be taken to mean no is not subject to any plausible objection. True, as Husak and Thomas note, this "proposal designed to make it more difficult for men to get away with rape might have the ... effect of making it harder for some women to get what they want." 87 But this cost, inevitable for any default rule, is in no way comparable to the costs that are incurred by the traditional approach that Husak and Thomas, among others, prefer. That approach makes it harder for other women to get what they want, in this case women who have sought to avoid male sexual impositions by expressing their desires in plain language. There can be little doubt about which set of frustrated expectations is more serious or more deserving of legal protection.

${ }^{86}$ Husak \& Thomas, supra note 83, at 114.

${ }^{87}$ Id. 
Although the "no"-means-no claim should not be controversial, the more serious difficulty is that this proposition offers surprisingly little help. In real cases, the "no" is often followed by some form of equivocal acquiescence, or even a "yes." How should the "no"means-no rule apply in cases like that?

One approach suggested is to use something like the Miranda rule. In police interrogation, a consent to talk about a crime is considered involuntary if an initial "no" is followed by any questions or comments that persuade the person to talk. ${ }^{88}$ The argument is that a similar approach should apply in rape cases: a woman's consent would be invalid if her "no" was followed by cajolery or psychological ploys that led her to acquiesce. ${ }^{89}$

That approach sounds plausible until you try to apply it to situations involving dates or acquaintances. Suppose a woman says "no" to her lover before dinner and then changes her mind after several hours of intimate conversation? Would the consent have to be considered invalid? That cannot be the right result. The only way to sort out these problems is to focus on the conduct that leads to a "yes"-in other words, whether the persuasions are improper. "No" means no just does not help sort out whether the things that happen after the "no" are legitimate or abusive. And even if the "no" is clear and persistent, the "no"-means-no rule is still insufficient because it only serves to establish nonconsent, and under existing law nonconsent is insufficient to establish rape: the prosecution must prove "force" in addition. ${ }^{90}$

\section{The Meaning of "Force"}

The other strand in current reform proposals is to tackle the problem by expanding the conception of force. Many rape reformers stress that force can take the form of strength that a man does not need to use. ${ }^{91}$ Force can involve not only physical violence but also other kinds of power. ${ }^{92}$ This approach reflects the theories of male dominance developed by Catharine MacKin-

${ }^{88}$ See Miranda v. Arizona, 384 U.S. 436, $473-74$ (1966).

${ }^{89}$ See ESTRICH, supra note 7, at 40-41 (contrasting the rule that "no" is insufficient to establish nonconsent in rape to the rule in custodial questioning that "a suspect's 'no' must mean no, and questioning must cease").

${ }^{90}$ See supra text accompanying note 76.

${ }^{91}$ See Estrich, supra note 82, at 1115.

${ }^{22}$ See $i d$. (noting that existing law "create[s] a gulf between power and force"). 
non $^{93}$ that are now supported by many moderate feminists ${ }^{94}$ and by several courts. ${ }^{95}$

Some women worry that the dominance approach, which is intended to strengthen women, may wind up making them feel weak and more vulnerable. ${ }^{96}$ The cultural effect of these debates is tricky, but it is not really decisive for the criminal law. The sexual pressure on women is real; the law cannot wish that away or wait until all men "get it."

The more important concern for law is that recognizing the power of male sexual pressure does not solve the legal problem because, as usual, a major part of the legal problem is a boundary ("line-drawing") problem. Despite the undoubted value of legal analysis or cultural criticism that points to commonalities between physical violence and social, economic, or psychological pressure, ${ }^{97}$ the job of legal scholarship is not finished until a workable boundary between permitted and regulated conduct has been identified. ${ }^{98}$ And in the case of rape, the boundary problem is acute. If

${ }^{93}$ See MACKINNON, supra note 3, at 40 (arguing that "[g]ender is . . . a question of power, specifically of male supremacy and female subordination").

${ }^{94}$ See, e.g., ESTRICH, supra note 7, at 63 (arguing that one of the problems with "force' as a standard is ... that it is too narrowly defined").

${ }^{95}$ See, e.g., State ex rel. M.T.S., 609 A.2d 1266, 1277 (N.J. 1992) (stating that the requirement of "physical force" is satisfied any time the defendant penetrates a woman against her will); State v. Etheridge, 352 S.E.2d 673, 680 (N.C. 1987) (holding that "force" may be "actual, physical force or . . . constructive force in the form of fear, fright, or coercion").

${ }_{96}^{6}$ See, e.g., Vivian Berger, Not So Simple Rape, CRIM. JUST. ETHICS, Winter-Spring 1988, at 69, 75 (reviewing ESTRICH, supra note 7) (arguing that Estrich's approach may lead the law to "patronize" women). A related theme is sounded and expanded in a number of recent revisionist attacks on the feminist program. See, e.g., KaTIE RoIPHe, The MORNING AfTer: SEX, FeAR, AND Feminism on CAMPus 163 (1993) (arguing that teaching women to "recognize" behavior as sexual harassment may train them to think like victims).

${ }^{97}$ See, e.g., Commonwealth v. Mlinarich, 498 A.2d 395, 416 (Pa. Super. Ct. 1985) (Spaeth, J., dissenting) (arguing that "forcible compulsion" includes nonphysical compulsion); see also Lucy R. Harris, Comment, Towards a Consent Standard in the Law of Rape, 43 U. CHI. L. REV. 613, 643-45 (1976) (arguing for the criminalization of sexual coercion via threat of nonphysical harm).

${ }^{98}$ Cf. Robin L. West, Legitimating the Illegitimate: A Comment on Beyond Rape, 93 Colum. L. REv. 1442 (1993). Professor West's article criticizes a male scholar's proposal to draw lines between permissible and impermissible sexual pressures, and suggests that the very effort to mark such a boundary and to condone conduct on one side of the line is in itself inappropriate. See id. at 1452-59. The article is filled with interesting and insightful cultural criticism, but its implication that such line-drawing efforts are inappropriate in principle seems unfair not only to the author of the proposal, but to the women who are seeking helpful responses to inadequacies in the law of rape. 
disparities in economic and social power are sufficient to establish coercion, then force is pervasive in human affairs. If disparity of size, strength, and fighting ability are sufficient to establish force, rape is implicit in nearly every heterosexual relationship.

The move to expand the conception of force thus has much truth to it but no stopping point. In that sense, it is too radical. That is a common reaction to Professor MacKinnon's approach. ${ }^{99}$ But the dominance approach is also too conservative because it remains linked to notions of force. In actual administration, it is almost certain to be held back by the cultural preconceptions that determine what force means to the many police, prosecutors, judges, and jurors who are not feminists. Efforts to expand accepted conceptions of force can offer interest and excitement to conversations within feminist circles, but as these approaches rest upon accordion-like notions of power or pressure, they inevitably lead the discussion into an area where boundaries will be unclear and social consensus will be elusive.

We all face pressures and constraints on our choices every day. The pressing problem for feminist jurisprudence and legal reform is to provide tools for determining which pressures are excessive or improper. A "dominance" analysis offers little guidance here, unless we want to treat conduct as rape whenever the pressures deployed are deemed "excessive," "unreasonable," or "unfair." A recent Pennsylvania decision takes essentially that view in equating the "forcible compulsion" required for rape with "using superior force-physical, moral, psychological or intellectual-to compel a person to do a thing against that person's volition." 100 But even if we by-pass the obvious vagueness problems entailed in deploying such a standard against economic inducements, emotional pressure, and the like, this approach will not necessarily work well for the women we want to protect, because there is no guarantee that prosecutors and juries will accept a feminist perspective on when such pressures are improper.

${ }^{99}$ See, e.g., Berger, supra note 96 , at 75 (arguing that ${ }^{\alpha}[t] \circ$ treat as victims in a legal sense all of the female victims of life is at some point to cheapen, not celebrate the rights to self-determination [and] sexual autonomy ... of women").

${ }^{100}$ Commonwealth v. Rhodes, 510 A.2d 1217, 1225 (Pa. 1986); see also Mlinarich, 498 A.2d at 404 (Spaeth, J., dissenting) (defining "forcible compulsion" to mean to constrain or compel "by physical, moral, or intellectual means or by the exigencies of the circumstances"); $c f$. MODEL PENAL CODE $\S 213.1$ (2)(a) (1980) (punishing conduct as "gross sexual imposition" if it produces submission to intercourse by "any threat that would prevent resistance by a woman of ordinary resolution"). 
Three recent proposals attempt to draw more specific lines. Professor Donald Dripps argues that physical violence should not be the only factor sufficient to render sexual intercourse criminal, and he proposes a crime of "sexual expropriation" to punish certain nonviolent impositions as an offense distinct from rape. ${ }^{101}$ His analysis rests on a "commodity theory" that sees "sexual cooperation as a service much like any other," in which "erotic assets" are exchanged for monetary or nonmonetary compensation. ${ }^{102}$

This concededly "unromantic notion of $\operatorname{sex}^{n 103}$ provides a poor basis for understanding the dynamics of personal relationships, and it tends to entrench and endorse much of the sexual pressure that women so often experience as problematic. Although Dripps seems to acknowledge that "some nonviolent pressures should be criminal, ${ }^{104}$ the only nonviolent impositions actually covered by his proposal are cases in which the woman is unconscious or mentally incompetent, or in which she has expressly refused consent. ${ }^{105}$ The Dripps proposal would thus impose no criminal sanctions in cases of silence or ambivalence about consent, nor would it punish cases of express acquiescence produced by nonviolent pressure, however serious. In a recent Montana case, a high school principal allegedly got a student's consent to sex by threatening to prevent her from graduating. ${ }^{106}$ The court held that its sexual assault statute required a threat of physical harm and that the principal's alleged conduct therefore was not criminal. ${ }^{107}$ Professor Dripps evidently would agree with the result, not only as a matter of statutory interpretation but as a matter of policy. Indeed, he concludes by "argu[ing] for limiting the reach of criminal liability to cases in which the defendant either causes sex through violence or engages in sex over the victim's expressed refusal. $" 108$

Professor Susan Estrich suggests a different approach. She, like Dripps, would treat an expressed refusal (but not silence or ambivalence) as sufficient to establish nonconsent. She goes further

${ }^{101}$ See Donald A. Dripps, Beyond Rape: An Essay on the Difference Between the Presence of Force and the Absence of Consent, 92 CoLUM. L. REv. 1780, 1799-1805 (1992).

${ }^{102} \mathrm{Id}$. at 1786.

${ }^{103} \mathrm{Id}$.

$10 \mathrm{Id}$. at 1800.

${ }^{105}$ See $i d$. at 1807 (including these conditions in a model sex offense statute).

${ }^{106}$ See State v. Thompson, 792 P.2d 1103 (Mont. 1990).

${ }^{107}$ See id. at 1106-07.

${ }^{108}$ Donald A. Dripps, More on Distinguishing Sex, Sexual Expropriation, and Sexual Assault: A Reply to Professor West, 93 CoLUM. L. REV. 1460, 1463 (1993) (emphasis added). 
than Dripps in two respects. She argues that "[ $t]$ he 'force' or 'coercion' that negates consent ought to be defined to include extortionate threats and misrepresentations of material fact." ${ }^{109}$ And she concludes that such conduct should be called "rape," not some other offense. ${ }^{110}$ This seems a sensible way to begin thinking about factors that taint consent. But Estrich unfortunately does not spell out her notion of either extortion or misrepresentation. Because her concept of rape could extend even to a partner who insincerely professes true love for his or her date, many committed feminists are dubious about Estrich's analysis. ${ }^{111}$ Without further detail, the approach seems either plausible but vague, or clear but far too broad.

The New Jersey Supreme Court's recent, much-discussed decision in State ex rel. M.T.S. ${ }^{112}$ adopts a third solution. The case dealt with the interpretation of a statute punishing conduct as "sexual assault" when intercourse is committed by "physical force or coercion." 113 The court held that this requirement is met by the force inherent in the act of intercourse itself, whenever the act is nonconsensual. ${ }^{114}$

This approach succeeds in criminalizing nonviolent sexual misconduct but with several costs. The statute prohibiting "force or coercion," without any mention of nonconsent, is in effect rewritten to prohibit nonconsensual intercourse without regard to force (other than that intrinsic to intercourse). Under this view criminality turns on the validity of consent; the court specified that consent must be "freely-given" $" 115$ but provided no standard for making this determination, beyond its rejection of physical violence as a touchstone. Thus, for cases where there is express acquiescence, induced by problematic means, the seemingly specific New

${ }^{109}$ ESTRICH, supra note 7, at 102-03.

${ }^{110}$ See id. at 103 ("The crime I have described may be a lesser offense . . . but it is a serious offense that should be called 'rape." ).

111 See, e.g., Berger, supra note 96, at 75 (arguing that Estrich's broad conception of force "may backfire and ultimately damage the cause of women"); Lynne $N$. Henderson, What Makes Rape a Crime?, 3 BERKELEY WOMEN's L.J. 193, 228 (1988) (reviewing ESTRICH, supra note 7) (criticizing Estrich for "poorly . . . thought out" proposals that "suffer from the same flaws and difficulties as current laws"). For a discussion of whether deception should invalidate consent, see Schulhofer, supra note 75, at 88-93.

112609 A.2d 1266 (N.J. 1992).

113 N.J. STAT. ANN. \& 2C:14-2c(1) (West 1982).

114 See M.T.S., 609 A.2d at 1276-77.

115 Id. at 1277. 
Jersey approach ultimately draws no line at all. And the court placed such misconduct in the same statutory grading category as physically violent rape, an offense that is punishable in New Jersey by a minimum of five years in prison. ${ }^{116}$

Dominance is not the way to get at this problem. The underlying concern here is to protect a woman's autonomy in matters of sexual choice. The autonomy concern needs to be addressed directly, not as a by-product of definitional debates about force.

\section{Protecting Autonomy}

Autonomy is not self-defining, of course. Stating the problem as an autonomy question amounts to a nonsolution if violations of autonomy are equated with coercion by excessive pressure.

An alternative approach is to define autonomy as the right to protection from those interferences that our culture and our legal system already consider impermissible. ${ }^{117}$ This seemingly minimalist approach to the problem has unexpected power in serving to identify sexual behavior that is unambiguously improper.

It is important to stress that in advocating reliance on this very "thin" conception of autonomy, I do not imply moral approval for all conduct outside its reach. Many troubling forms of sexual pressure manage to avoid use of threats that are prohibited by existing principles within our culture. Economic pressure, for example, can have powerfully constraining effects on freedom of action, and decisions to accept sexual intimacy for economic reasons are appropriately regarded as "unfortunate, unattractive, or degrading." 118 That such pressures will not always violate the minimalist conception of autonomy I develop here is not a reason to insulate them from moral or psychological criticism or from the eventual adoption of more ambitious legal standards. The conception of autonomy I want to spotlight is not intended as the end of dialogue or legal development. Rather, it simply offers a baseline that is relatively uncontroversial in its moral and cultural presuppo-

${ }^{116}$ Because M.T.S. was a juvenile case, the trial court was able to grant the defendant a suspended sentence. See $i d$. at 1269. In an adult prosecution, New Jersey law would not permit suspension of the minimum five-year term except under "truly extraordinary and unanticipated circumstances." State v. Johnson, 570 A.2d 395, 398 (N.J. 1990) (citation omitted).

117 See Schulhofer, supra note 75, at 69-71 (developing a theory of sexual autonomy based on existing conceptions of impermissible interference with bodily integrity and freedom of choice).

${ }^{118} \mathrm{Id}$. at 86. 
sitions. Yet this minimalist starting point has significant power to extend the scope of available legal protections.

Several examples will illustrate the far-reaching implications of the conception of autonomy that is already broadly accepted within our culture. First, when is consent lacking? "No" means no, obviously. But an intrusion on the person requires more than just the absence of a clear "no." A physical intrusion on the person requires actual permission.

Would anyone think that a medical patient's ambivalence, or an ambiguous "maybe," was a consent to medical treatment or surgery? Obviously, anything less than clear affirmative permission would never count as consent. Imagine Atlas, an Olympic weightlifter, consulting a doctor about whether to have surgery on his elbow. The doctor really wants to perform the operation. He thinks Atlas will be very happy with the experience. But the weightlifter is uncertain. He thinks things may not work out the way the doctor has promised. And there is a risk of picking up a serious infection. So Atlas hesitates, says he just is not sure. Can the doctor just go ahead and start cutting? Would we ever treat the weightlifter's silence or indecision as equivalent to consent? No, obviously, but why not? No one compelled him to submit. If he really objected, all he had to do was say sol Yet we would never consider silence or ambivalence as equivalent to consent for surgery. To say that is not to patronize Atlas; it is simply to recognize an obvious violation of the physical autonomy of his person.

Why should the physical autonomy of a woman's body not be entitled to the same respect in a sexual encounter? Clear proof of an unequivocal "no" should not be required. Consent for an intimate physical intrusion into the body should mean in sexual interactions what it means in every other context-affirmative permission clearly signaled by words or conduct. ${ }^{119}$ There are many ways to make permission clear without verbalizing the word "yes," and permission certainly need not be in writing. But permission must be an affirmative indication of actual willingness. Silence and ambivalence are not permission. ${ }^{120}$

${ }^{119}$ See, e.g., WASH. REV. CODE ANN. § 9A.44.010(6) (West 1988) (defining consent to mean "that at the time of the act of sexual intercourse there are actual words or conduct indicating freely given agreement to have sexual intercourse"); M.T.S., 609 A.2d at 1278 (defining consent as "affirmative and freely-given authorization for the specific act of sexual penetration").

${ }^{120}$ Contextual differences between surgery and sexual intimacy suggest somewhat different mechanisms for protecting autonomy in the two situations. The doctor's 
Next, what if a woman does agree? What kinds of constraints violate her autonomy? Autonomy cannot mean freedom from all constraints upon choice, but it does entail freedom from those constraints that our culture identifies as illegitimate. The scope of that freedom is marked by the rights to bodily integrity and personal independence that existing legal principles already protect. ${ }^{121}$ This modest conception of personal autonomy offers boundaries that are specific and, yet, far reaching.

One example is sexual harassment in the workplace. This looks like an area that is hardly ripe for criminal sanctions. But if a supervisor tries to get sexual favors by offering a promotion (or by threatening to veto one), he is confronting the employee with alternatives (no matter whether we call them offers or threats) that his position gives him no right to impose. If the supervisor used his position to get an economic payoff from the employee, he would be guilty of extortion. ${ }^{122}$ If a professor threatened to withhold a good grade or a good recommendation until he got some cash from a student, again he would be guilty of extortion. ${ }^{123}$

The worker or student should have the same right to control her sexuality that she has to control her wages or her bank account. What makes the woman's consent invalid is not that the supervisor's act involves too much pressure. What makes the consent invalid is that rules already settled in our culture deny the supervisor the right to require an employee to choose between her promotion and her legally protected interests. One of those interests should beand is-her sexual independence. For the same reason, the high school principal who allegedly obtained sex from a student by threatening to block her graduation ${ }^{124}$ should certainly be guilty of a crime.

expertise can justify a special duty of disclosure, and the complexity of the risks may suggest the need for a conception of informed consent much more stringent than that which is appropriate in a sexual encounter.

${ }^{121}$ See Schulhofer, supra note 75, at 69-71 (discussing the scope and objectives of legal protection of autonomous choice in the area of sexual intimacy).

${ }^{122}$ See MODEL PenAl CODE \$223.4 commentary at 223 (1980) (offering as an example of extortion the case of a "foreman in a manufacturing plant who requires the workers to pay him a percentage of their wages on pain of dismissal or other employment discrimination").

${ }^{123}$ See id. (noting as an example of extortion the case of a "law professor who obtains property from a student by threatening to give him a failing grade or to influence a prospective employer to hire someone else").

124 See supra text accompanying notes 106-07. 
Two variations will make the implications clearer. Suppose that a highly paid fashion model wants to land a film role to enhance her career. The company's casting director says that unless she sleeps with him, she will not get the part. If you are looking for excessive pressure, this case will seem a lot harder than that of the student or employee. You may not feel sympathy for the model at all. But whether you feel sympathy or not, the violation of her autonomy is the same as in the previous cases. The man's action is extortionate, just as if he had insisted on a side-payment in cash. There is an improper constraint on the woman's freedom of choice under background rights that are already settled in our culture.

The converse of the model's situation, the "hard case" for this analysis, is that of a needy mother of four who finds a partner willing to support her. Suppose that the relationship deteriorates, and the man threatens to kick her out of the apartment unless she continues to meet his sexual demands. Obviously, the needy mother has far less freedom of choice than the successful fashion model does. But the relevant question has to be whether the man's threatened actions are illicit. In the model's situation, the pressure may be slight, but it is clearly impermissible. In the mother's case, the pressure, though severe, might not be illicit. A sexual quid pro quo is not a legitimate condition of ordinary employment, but sexual fulfillment is, for both men and women, an appropriate and valued goal of ongoing, intimate personal relationships. Thus, although the man's action in imposing a sexual condition on his willingness to continue his relationship with the needy mother could be criticized as insensitive in many contexts, it nonetheless involves an exercise of his autonomy that society ordinarily considers legitimate and worthy of social protection. It makes sense to ask whether the nature of the relationship is sufficient to give her a right to remain in the apartment or to receive financial support, and if she does have such a right, the man's threats should render any consent to sex invalid. But if existing norms do not protect her from this sort of economic pressure, then her decision to remain in the relationship, although highly constrained, is not improperly tainted, and her consent to sex would therefore be valid.

With these principles in mind, we can return to the cases mentioned earlier-the man who takes the woman's car keys and the man whose intimidated girlfriend no longer tries to fight back. In the first case, there is a kind of consent, ultimately the woman says "OK," but the consent is tainted by a clear violation of her right to leave. In the second case, there is never any affirmative permission 
at all. These cases make clear that one thing missing in the law of rape is some way to punish sexual misconduct that is not physically violent. It is as if we had a law against armed robbery but no law against theft. The way to fill that gap is not to try expanding what we mean by force but to have statutes punishing, as an offense distinct from forcible rape, any sexual imposition without valid consent. Thus, the men in these two cases should, at a minimum, be convicted of sexual misconduct.

We get these results without having to sort out degrees of force and without having to treat women as dominated or disempowered. The key is in the background structure of rights and privileges that determine what uses of personal power and institutional position are permissible, against either the weak or the strong, against either men or women in our society.

This approach identifies a baseline of existing rights, and it leaves room for evolution in the standards for valid consent. Respect for a woman's autonomy should mean that her interest in controlling her sexual choices receives just as much protection as any person's interest in controlling her property, her labor, or her freedom of action in other areas of life.

\section{SENTENCING}

I turn now to a set of problems facing female offenders. Women constitute an ever-increasing proportion of all defendants, and they are facing increasingly serious charges, especially in the federal courts. ${ }^{125}$ One explanation attributes these changes to women's increasing independence and growing participation in the workforce. ${ }^{126}$ But this "liberation hypothesis" is now generally discredited as an explanation for women's apparently rising crime

${ }^{125}$ See Bureau of Justice Statistics, U.S. Dep't of Justice, Women in Prison 3 (1994) [hereinafter WOMEN IN PRISON 1994] ("[T]he number of women sentenced for a violent offense rose from 8045 to 12,400 during the [1986-1991] period."); RITA J. Simon \& Jean Landis, The Crimes Women Commit, The Punishments They RECEIVE 78 (1991) (reporting that from 1980 to 1985, the female incarceration rate increased from 11 per 100,000 to 17 per 100,000).

${ }^{126}$ See, e.g., Freda AdLer, Sisters in Crime: The RiSE Of The New Female CRIMINAL 13-15 (1975) (claiming that women's advances in "fields of legitimate endeavor" have been paralleled by advances in "the world of major crimes"); RITA J. SIMON, WOMEN AND CRIME 19 (1975) (noting that a major hypothesis regarding women's criminality is that women's participation in financial and white collar crimes should increase as their participation in the workplace increases, as such participation will expose them to greater opportunities for committing such crimes). 
rate. ${ }^{127}$ Thelma and Louise notwithstanding, economic and psychological liberation seem to play a small role in accounting for the growth in women's rates of offending. ${ }^{128}$ Far more important factors appear to be the feminization of poverty and the "War on Drugs." 129

Along with the increase in the number of women facing long sentences is a major shift in the way they are sentenced. Until the late 1970s, American sentencing judges had essentially unbridled discretion. ${ }^{130}$ This approach seemed to help women, as they often received less severe punishment than men convicted of similar crimes. ${ }^{131}$ The reason for this preferential treatment remains unclear. Some of the differences seem traceable to something like "chivalry"-male judges felt protective toward a female defendant, except when she violated gender norms by committing a violent crime. ${ }^{132}$ Probably a more important factor was judges' desires to protect the children of convicted women. ${ }^{133}$ In any event, discretion helped women, although maybe not for the right reasons.

But that was the 1950s and 1960s. In the 1990s, sentencing discretion has gone the way of the dinosaur, especially in the federal courts. The new order is dominated by mandatory minimums and inflexible guidelines. ${ }^{134}$ Part of the egalitarian spirit of our age is

${ }^{127}$ See Joseph G. Weis, Liberation and Crime: The Invention of the New Female Criminal, CRIME \& SOC. JUST., Fall-Winter 1976, at 17, 17 (challenging the assertion that a causal relationship exists between women's liberation and their criminal behavior).

${ }^{128}$ See, e.g., Roland Chilton \& Susan K. Datesman, Gender, Race, and Crime: An Analysis of Urban Arrest Trends, 1960-1980, 1 GENDER \& Soc'y 152, 167-68 (1987) (arguing that the most plausible explanation for rising women's crime rates, in particular black women's crime rates, is their declining economic situation).

${ }^{129}$ See id.

${ }^{130}$ See Stephen J. Schulhofer, Due Process of Sentencing, 128 U. PA. L. REv. 733, 735-37 (1980) (describing sentencing regimes that were common until the 1970s).

${ }^{131}$ See Ilene H. Nagel \& John Hagan, Gender and Crime: Offense Patterns and Criminal Court Sanctions, in 4 CRIME AND JUSTICE: AN ANNUAL REVIEW OF RESEARCH 91, 129-34 (Michael Tonry \& Norval Morris eds., 1983) (finding that women receive preferential treatment in the sentencing process); Darrell Steffensmeier \& John H. Kramer, Sex-Based Differences in the Sentencing of Adult Criminal Defendants: An Empirical Test and Theoretical Overview, 66 Soc. \& Soc. REs. 289, 297 (1982) (finding that "[p]referential treatment of female defendants appears to be consistent ... across most offense categories").

132 See Nagel \& Hagan, supra note 131, at 112-15 (articulating the "chivalry/paternalism thesis").

${ }^{133}$ See Kathleen Daly, Rethinking Judicial Paternalism: Gender, Work-Family Relations, and Sentencing, 3 GENDER \& SOC'Y 9, 19-22 (1989) (discussing the significant influence that the protection of children has on the sentencing of female defendants).

134 See Stephen J. Schulhofer, Assessing the Federal Sentencing Process: The Problem 
the directive in the Sentencing Reform Act of 1984 that federal sentencing guidelines must be "entirely neutral" as to the race, socioeconomic status, and sex of the offender. ${ }^{135}$

In practice, that neutrality has been a mixed blessing. To illustrate the paradoxes of neutrality, I will outline the structure of sentencing under guidelines in the federal courts and then take up three issues that pose special problems for women: pregnancy, children, and recidivism.

\section{A. The Federal Sentencing Guidelines}

The guidelines promulgated by the United States Sentencing Commission establish a normal sentencing range for each offense and identify aggravating and mitigating factors that either alter the normal sentence range or provide an authorized basis for an upward or downward departure. ${ }^{136}$ Gircumstances not identified by the Commission are impermissible grounds for upward or downward departure unless they involve some factor "not adequately taken into consideration by the Sentencing Commission in formulating the guidelines." ${ }^{137}$ Applying the egalitarian mandate of the Sentencing Reform Act of 1984, the Commission listed a number of factors that ordinarily cannot justify a departure from the guideline sentence. ${ }^{138}$ Among the factors "not ordinarily relevant" are age, mental and emotional conditions, physical condition, and family responsibilities. ${ }^{139}$ Gender is even more suspect. This factor, the Commission has said, is never relevant. ${ }^{140}$

Is Uniformity, Not Disparity, 29 AM. CRIM. L. REV. 833, 851 (1992) (stating that "[t]he federal sentencing process is pervaded by unwarranted similarities in the treatment of substantively distinguishable cases"); Stephen J. Schulhofer, Rethinking Mandatory Minimums, 28 WAKE FOREST L. REV. 199, 200-02 (1993) (describing mandatory minimums and their goals).

135 Pub. L. No. 98-473, tit. II, ch. II, § 217(a), 98 Stat. 1987, 2019 (codified as amended at 28 U.S.C. $\$ 994(d)$ (1988)).

${ }^{136}$ See 18 U.S.C.S. app. § 1 A (Law. Co-op. 1994); see also Stephen Breyer, The Federal Sentencing Guidelines and the Key Compromises upon Which They Rest, 17 HOFSTRA L. REV. 1, 8-31 (1988) (explaining the background and operation of this system).

137 18 U.S.C. $\$ 3553$ (b) (1988).

${ }^{138}$ See 18 U.S.C.S. app. \$ 5H (Law. Co-op. 1994) (listing offender characteristics not ordinarily relevant to the determination of whether a sentence should be outside the applicable guideline range).

${ }^{139} 18$ U.S.C.S. app. $\$ 5 \mathrm{H} 1.1$ (regarding age), § $5 \mathrm{H} 1.3$ (regarding mental and emotional conditions), $\$ 5 \mathrm{H} 1.4$ (regarding physical conditions), § $5 \mathrm{H} 1.6$ (regarding family responsibilities).

${ }^{140}$ See 18 U.S.C.S. app. $\$ 5 H 1.10$. 
Against the background of prior judicial sentencing practices, these changes will clearly produce more severe sentences for women. That in itself cannot tell us that the changes are wrong. A woman convicted of a crime should face the same penalty as a similarly situated man. But there are several special problems. The following section explores the problems for women that are presented by this seemingly sensible conception of neutrality.

\section{B. The Paradoxes of Neutrality}

\section{Pregnancy}

The first problem for a neutrality approach is that men do not get pregnant. Yet in United States v. Pozzy, ${ }^{141}$ the First Gircuit held that a defendant's pregnancy ordinarily cannot justify reducing a long prison sentence that the Guidelines would otherwise require. ${ }^{142}$

The intuition that Pozzy sets an unjustifiably harsh rule is understandable, and critics of the Guidelines sharply attacked it. Professor Albert Alschuler ${ }^{143}$ and Professors Marc Miller and Daniel J. Freed ${ }^{144}$ argue that the holding in Pozzy is unsound. Professor Myrna S. Raeder, in the most comprehensive study on the issue, concludes that "[u]nquestionably, pregnant women ... should be eligible for downward departures in the current Guidelines regime." 145

This issue, however, is a troubling one, not only for fair sentencing policy, but for women's interests in particular. No one likes sending a pregnant woman to prison. But convicted men enter prison with serious medical problems too. For too long, women's interests have been undermined by practices that singled out

141902 F.2d 133 (1st Cir.), cert. denied, 498 U.S. 943 (1990).

142 See id. at 138-39. On occasion, district judges in the Second Circuit have granted downward departures on the basis of pregnancy, without being challenged on appeal. See Myrna S. Raeder, Gender and Sentencing: Single Moms, Ballered Women, and Other Sex-Based Anomalies in the Gender-Free World of the Federal Sentencing Guidelines, 20 PEPP. L. REv. 905, 948 (1993) (discussing Second Circuit cases that neglected to follow the standard set forth in Pozzy).

${ }_{143}$ See Albert W. Alschuler, The Failure of Sentencing Guidelines: A Plea for Less Aggregation, 58 U. CHI. L. Rev. 901, 911 (1991) (criticizing Pozzy).

14 See Marc Miller \& Daniel J. Freed, Offender Characteristics and Victim Vulnerability: The Differences Between Policy Statements and Guidelines, FED. SENTENCING REP., June-July 1990, at 3, 3-4 (criticizing restrictions on the departure power in cases such as Pozzy).

${ }^{145}$ Raeder, supra note 142, at 949. 
pregnancy for different treatment than that accorded health problems in general. ${ }^{146}$ Our starting point on this question should therefore be the assumption that, all else equal, we will strive to treat pregnancy like other medical conditions. Pregnant women, therefore, should probably lose on their claim to special treatment, unless there is reason to treat pregnancy differently from the health problems that male inmates suffer.

One special feature of pregnancy is that poor medical care in prison may endanger not only the offender but an innocent party, the child. If the prison cannot provide safe birthing facilities and adequate neonatal care, there is surely a case for special treatment. But because pregnancy, unlike other medical problems, is a shortterm condition, a sentence reduction is not necessary to deal with this concern; the judge can simply delay the date of entry into prison until after the child is born. ${ }^{147}$ In any event, pregnant inmates are no longer unusual, and many state and federal prisons now provide modern facilities that can equal or exceed the quality of care these women would be likely to receive in the outside world. ${ }^{148}$

Other major differences between pregnancy and the medical concerns of male inmates tend to undermine claims for special treatment. Pregnancy usually is not life-threatening, and it often occurs by choice, unlike cancer, for example. As a result, any rule allowing sentence reductions for pregnancy would have unique potential for manipulation. ${ }^{149}$ I am not enthusiastic about the results in the pregnancy cases, but on balance the courts are right to disregard pregnancy in most circumstances. ${ }^{150}$

${ }^{146}$ See, e.g., Geduldig v. Aiello, 417 U.S. 484, 494 (1974) (holding that the exclusion of pregnancy from disabilities covered under a California statute did not deny women equal protection of the law).

${ }^{147}$ This approach will raise a new question, of course: how to deal with the offender who has responsibility for an infant child. Under some (but by no means all) circumstances, such family responsibilities could justify more lenient punishment of the convicted mother. For a discussion of this issue, see infra notes 151-60 and accompanying text.

${ }^{148}$ See, e.g., Anita G. Huft et al., Care of the Pregnant Offender, 3 FED. Prisons J. 49, 51 (1992) (discussing the health-care facility at Lexington, Kentucky for federal inmates who have high-risk pregnancies).

${ }^{149}$ Cf. United States v. Arize, 792 F. Supp. 920, 921 (E.D.N.Y. 1992) (granting downward departure where a female drug courier was unaware of her pregnancy at the time of the offense and where loss of child custody was possible).

${ }^{150}$ The issue needs to be approached case-by-case because pregnant offenders (many of whom have drug or alcohol problems) often face high-risk pregnancies. If ajurisdiction's prisons do not have appropriate obstetrical services available, there is 


\section{Family Ties}

Although pregnancy ordinarily should not be treated differently from the medical problems that men suffer, a "neutral" approach to family ties is a different matter. In the old days, white-collar defendants were able to win leniency by using their family responsibilities to evoke sympathy. ${ }^{151}$ Judges were reluctant to take the breadwinner away from his children, and the ignominy of accusation and conviction were often viewed as substantial sanctions for the white-collar defendant. ${ }^{152}$ That instinct helped middle-class offenders, but the unemployed, especially underclass blacks, often received harsher sentences. ${ }^{153}$ The Sentencing Commission responded to the race and class biases of the old system by specifying that community ties, employment, and family responsibilities ordinarily will not justify a departure from the guideline sentencing range. ${ }^{154}$

This is generally a sensible rule, but as usual, it was crafted with men in mind. The "family responsibility" rubric is the same, but the real problem is different when the defendant is a woman with three preschool age children. Compared to a male prisoner, a female pri-

a strong case for special consideration. But a similar point can be made with respect to other medical conditions that cannot be treated properly in prison. A male inmate's health problems ordinarily endanger only the offender himself, but improper treatment and consequent risks of permanent injury or death are not permissible punishments for whatever offense sent the offender to prison. See Estelle v. Gamble, 429 U.S. 97, 104 (1976) (holding that "deliberate indifference to serious medical needs of prisoners" violates the Eighth Amendment), cert. denied, 434 U.S. 974 (1977).

151 See Stanton WheEler et al., SitTing in JUdgment: The Sentencing of WHITE-COLLAR CRIMINALS 152-54 (1988) (reporting that prior to the recent sentencing guidelines, judges imposed either short sentences or no prison term on whitecollar offenders "to avoid eliminating the [offender's] contribution to community and family").

${ }^{152}$ See id. at $144-45$ (reporting that judges typically considered public indictment, conviction, and loss of community status to be significant forms of punishment for the white-collar offender and that ${ }^{~ "}[\mathrm{~m}]$ ost judges . . . . wonder whether.the imposition of additional suffering is justifiable").

153 Available statistical studies do not, however, show unambiguous racial disparities in sentencing. See 1 RESEARCH ON SENTENCING: THE SEARCH FOR REFORM 93 (Alfred Blumstein et al. eds., 1983) (noting that "[w]hile there is no evidence of a widespread systematic pattern of discrimination in sentencing, some pockets of discrimination are found for particular judges, particular crime types, and in particular settings").

${ }^{154}$ See 18 U.S.C.S. app. § 5H1.5-.6 (Law. Co-op. 1994) (stating that employment records, family ties and responsibilities, and community ties "are not ordinarily relevant in determining whether a sentence should be outside the applicable guideline range"). 
soner is twice as likely to have dependents who lived with her prior to her incarceration. ${ }^{155}$ A welfare check can often replace the only kind of family support that many male offenders ever provide, but when the mother goes to prison, the children lose their primary caretaker. This may not be a disaster for the children if the parent is an abusive drug addict or if close relatives can offer a stable and supportive home. But children are much more likely to face problematic alternatives when the incarcerated parent is their mother. Among male prisoners who have minor children, $88.5 \%$ report that the children are living with their mother, while only $22.1 \%$ of the female prisoners with minor children report that those children are living with their father. ${ }^{156}$ When long-term imprisonment of the mother will mean uncertain placements in foster care for all of a child's formative years, the social cost of "neutral" policy can be enormous. Yet $10.5 \%$ of female inmates (compared to only $1.7 \%$ of male inmates) have children who are assigned to a foster home or to an institutional placement after the parent's incarceration. ${ }^{157}$

The rule making family ties irrelevant thus creates a false equality between offenders in very different situations. It also makes fairness among offenders the sole question, when fairness to the children should be one of the court's major concerns. Equal treatment here-if it is equal treatment-can have a devastating effect on young lives. Yet in most of the federal circuits, courts have been "fairly hostile to child-based departures," 158 even when the offender was the single mother of five young children. ${ }^{159}$ As a result, the

${ }^{155}$ In $1986,52.6 \%$ of all female prisoners, but only $27.5 \%$ of all male prisoners, had been living with minor children just before they entered prison. See BUREAU OF JUSTICE STATISTICS, U.S. DEP'T OF JUSTICE, WOMEN IN PRISON 6 (1991) [hereinafter WOMEN IN PRISON 1991] (noting that $67.5 \%$ of female prisoners, but only $54.4 \%$ of male prisoners, had minor children when they entered prison, and that among the prisoners who had minor children, $78 \%$ of the women, but only $50.5 \%$ of the men, had lived with those children before entering prison).

${ }^{156}$ See id.

${ }^{157}$ See id. (noting that percentages are based on those inmates who had children under age 18).

${ }^{158}$ Raeder, supra note 142, at 945; see also United States v. Bieri, 21 F.3d 811, 814, 817-18 (8th Cir.) (denying downward departure when both the mother and father of two children, ages four and seven, were convicted of drug violations), cert. denied, 115 S. Ct. 208 (1994).

${ }^{159}$ See United States v. Headley, 923 F.2d 1079, $1082-83$ (3d Cir. 1991) (finding that although the district court had the power to depart downward when sentencing a mother of five, no court that had considered the issue had found parenthood to be an extraordinary circumstance justifying such a departure); $c f$. United States v. Chestna, 962 F.2d 103, 107-08 (1st Cir.) (affirming the district court's denial of downward departure based on the convict's position as the mother of three young 
equal treatment concept has been a disaster, not just for women, but for sensible policy. What we now need is more discretion, and more recognition of family ties as a legitimate basis for a shorter sentence or a less restrictive type of incarceration.

Such an approach need not entail a formal privilege of special treatment for women as such, because departures presumably should be authorized for primary caretakers or single parents of either gender under appropriate circumstances. But the appearance of formal equality here should not by itself satisfy us that a special departure rule would be evenhanded and fair. The reality is that such a departure rule will not look, and will not be, fully neutral between the sexes. Nearly all of the offenders who will benefit from it will be women. ${ }^{160}$ An overwhelmingly disproportionate impact of this sort should raise serious fairness concerns in most contexts. What makes such an impact tolerable in connection with sentencing is the manner in which the incarceration of single parents affects their children.

\section{The Likelihood of Recidivism}

Recidivism poses a third problem for the equal treatment approach. A key factor in determining guideline sentencing ranges is the need for incapacitation, based on the likelihood of recidivism and especially the likelihood of future violence. Sentencing tables reflect judges' perceptions about the potential violence of the typical offender, ${ }^{161}$ and of course the typical offender is male.

children), cert. denied, 113 S. Ct. 334 (1992). In the Second and Ninth Circuits, the courts have been somewhat more willing to view a female offender's family responsibilities as a permissible basis for a downward departure under some circumstances. See, e.g., United States v.Johnson, 964 F.2d 124, 129-31 (2d Cir. 1992) (affirming a downward departure based on extraordinary family circumstances consisting of the defendant having sole responsibility for raising four young children); Raeder, supra note 142, at 942-44 (discussing the Second and Ninth Circuits' willingness to grant a downward departure for single-parent mothers and noting one case in which the Tenth Circuit did so as well). On occasion, male defendants have benefitted from such departures as well. See, e.g., United States v. Sclamo, 997 F.2d 970, 972-74 (1st Cir. 1993) (affirming downward departure for a man who played an important role in the development of an emotionally disturbed child with whom he lived).

${ }^{160}$ See supra notes 155-57 and accompanying text (discussing the fact that female offenders are much more likely than male offenders to have dependents living with them prior to incarceration, and noting that children are more likely to suffer when the incarcerated parent is their mother).

${ }^{162}$ For example, in the federal system, the U.S. Sentencing Commission generally attempted to follow typical past practice in setting guideline sentencing ranges for 
The danger that a first or second offender will return to crime, especially to violent crime, is not the same for women as it is for men. This is not simply a false stereotype. Nor is it an area where we can make accurate judgments by excluding group generalizations and by relying entirely upon facts other than the individual's gender. Women really are different in this respect. Whether as a result of nature or nurture, and in this case the differences are probably due to both, women (including female offenders) are far less prone to violent aggression than are men. ${ }^{162}$

Modern equal protection doctrine seems strongly, perhaps unalterably, opposed to reliance upon statistical differences between the sexes as a basis for justifying categorical differences in treatment. In Craig $v$. Boren, ${ }^{163}$ the Supreme Court held unconstitutional an Oklahoma law that prohibited the sale of $3.2 \%$ beer to males under the age of 21 but permitted sales to females over the age of $18 .{ }^{164}$ The state got nowhere with statistics indicating that young males were more likely than females to drive while intoxicated. ${ }^{165}$ The Court noted that the state's statistics were subject to "obvious methodological problems," and that properly analyzed, the "statistical disparities between the sexes [were] not substantial."166 Nonetheless, the Court also stressed broader principles; it concluded that "proving broad sociological propositions by statistics is a dubious business, and one that inevitably is in tension with the normative philosophy that underlies the Equal Protection Clause." 167

Although Craig $v$. Boren might be explained by the fragility of the statistical differences that the State invoked, the same is not true of Reed v. Reed, ${ }^{168}$ Frontiero $v$. Richardson, ${ }^{169}$ and Weinberger $v$.

both first offenders and repeat offenders. See Breyer, supra note 136, at 7 ("[I]n creating categories and determining sentence lengths, the Commission, by and large, followed typical past practice, determined by an analysis of 10,000 actual cases." (citations omitted)).

${ }^{162}$ See supra text accompanying note 9 . For a discussion of repeat violence by women who have already committed a first offense, see infra notes $182-83$ and accompanying text.

163429 U.S. $190(1976)$.

${ }^{164}$ See id. at $190-91$.

${ }^{165}$ See id. at 200-04.

${ }^{166}$ Id. at 202, 203 n.16. In one random survey of Oklahoma City drivers, bloodalcohol levels indicating intoxication were found in $14.6 \%$ of the male drivers and $11.5 \%$ of the female drivers. See id. at 203 n.16.

${ }^{167}$ Id. at 204.

168404 U.S. 71, 76-77 (1971) (holding that a statutory scheme that draws distinctions between sexes solely for administrative convenience violates the Constitution).

${ }^{169} 411$ U.S. 677, 690-91 (1973) (finding that statutes that accord "differential 
Wiesenfeld. ${ }^{170}$ In these cases the Court struck down efforts to use sex as a decision-making factor, even though sex appeared to have substantial value in predicting an admittedly important fact. In Reed, the state's apparent premise, in preferring men to women as administrators for decedents' estates, was that men were more likely than women to have experience in formal business matters. ${ }^{171}$ In Frontiero and Wiesenfeld, Congress had mandated hearings on dependency for men but not for women seeking certain statutory benefits, on the ground that husbands were less likely to be dependent on their wives than vice versa. ${ }^{172}$ The Court held that such generalizations, even if empirically accurate, could not justify categorically different treatment of the sexes. ${ }^{173}$ The hostility to empirical generalization in these cases nonetheless may be explained by two facts. First, the differences between the sexes were themselves the products of gender discrimination and cultural impediments to women's ability to lead independent lives. Second, the facts for which gender was used as a proxy (business experience and dependency) could be ascertained more directly and more accurately by a factual hearing.

Closer to the present problem-that is, sharp, statistically valid gender differences that are not simply the results of past discrimination-is City of Los Angeles v. Manhart. ${ }^{174}$ In Manhart, the Supreme Court barred employers from using male-female differences in life expectancy as a basis for requiring women as a group to pay higher pension-annuity premiums. ${ }^{175}$ Technically, Manhart held only that the salary differentials violated the nondiscrimination requirements of Title VII of the Civil Rights Act of $1964,{ }^{176}$ but the Court's

treatment to male and female members of the uniformed services for the sole purpose of achieving administrative convenience" violate the Due Process Clause of the Fifth Amendment).

${ }^{170} 420$ U.S. $636,637-39$ (1975) (finding unconstitutional a gender-based differential in Social Security survivors benefits which discriminated against men whose wives were deceased); see also Califano v. Goldfarb, 430 U.S. 199, $201-02$ (1977) (finding unconstitutional a gender-based differential in Social Security survivors benefits which required a widower to show dependence on his deceased wife).

${ }^{171}$ See Craig, 429 U.S. at 202 n.13.

172 See Wiesenfeld, 420 U.S. at 644 (noting that "the framers of the Act legislated on the 'then generally accepted presumption that a man is responsible for the support of his wife and children'" (citation omitted)); Frontiero, 411 U.S. at 681 (surmising that Congress intended to make an economical law that took advantage of the fact that women tend to be the dependant spouse).

${ }^{173}$ See, e.g., Craig, 429 U.S. at 202 n.13; Frontiero, 411 U.S. at 688-89.

174435 U.S. 702 (1978).

${ }^{175}$ See id. at 707-11.

${ }^{176}$ Pub. L. No. 88-352, tit. VII, § 703(a), 78 Stat. 241, 255 (codified as amended 
reasoning would seem to suggest that such differential treatment would, in the case of a public employer, violate the Equal Protection Clause as well. ${ }^{177}$

One obvious argument for gender distinctions in sentencing is that, in contrast to the pension-annuity situation, the purpose and the primary effect of differential treatment in sentencing would be to help women, not to impose additional burdens on an already disadvantaged group. ${ }^{178}$ But the cases leave little if any room for the "benign purpose" path around the neutrality requirement of the Equal Protection Clause. Women were more favorably treated by the gender classifications held unconstitutional in Craig, Frontiero, and Wiesenfeld. Only when more favorable treatment for women can be seen as compensating for disadvantageous conditions suffered by women in the past does the Court seem prepared to uphold genderbased affirmative action remedies. ${ }^{179}$ If this perspective is controlling, the sentencing of female offenders seems a poor case for affirmative action preferences. Yet does it really make sense, either

at 42 U.S.C. $\$ 2000 \mathrm{e}-2(\mathrm{a})(1)(1988)$ ) ("It shall be an unlawful employment practice for an employer ... to ... discriminate against any individual with respect to his compensation, terms, conditions, or privileges of employment ....").

17 See Manhart, 435 U.S. at 711. Because Manhart was a Title VII case, there was no need to prove that differential treatment was adopted because of, and not simply in spite of, the gender of the disadvantaged group. $C f$. Washington v. Davis, 426 U.S. 229,239 (1976) (holding that a facially neutral classification violates the Equal Protection Clause only when there is proof of purposeful discrimination). But that requirement appears inapplicable in constitutional challenges to statutes that draw explicit distinctions along racial or gender lines. See, e.g., Craig, 429 U.S. at 204, 210 (holding that an explicit gender-based differential in an Oklahoma statute violated the Equal Protection Clause, without requiring proof of discriminatory purpose, when the differential was not substantially related to a legitimate statutory objective). In any event, the statutory holding in Manhart could be read to imply that categorical gender differences in sentencing guideline ranges would violate requirements of gender neutrality in the Federal Sentencing Reform Act of 1984, Pub. L. No. 98-473, tit. II, ch. II, $\$ 217($ a), 98 Stat. 1987, 2019 (codified as amended at 28 U.S.C. \$994(d) (1988)), even if such sentencing differentials were supported by statistics indicating substantial gender differences in the rate and seriousness of recidivism.

${ }^{178}$ Of course, seemingly favorable treatment has the potential to reinforce stereotypes and thus to backfire in the long run. See Orr v. Orr, 440 U.S. 268, 283 (1979) (noting that " $[1]$ egislative classifications which distribute benefits and burdens on the basis of gender carry the inherent risk of reinforcing stereotypes about the 'proper place' of women and their need for special protection"), cert. denied, 444 U.S. 1060 (1980). All "benign" preferences are subject to this caveat.

${ }^{179}$ See, e.g., Califano v. Webster, 430 U.S. 313, $317-18$ (1977) (upholding a Social Security-related statute which provided higher old-age benefits for women); Schlesinger v. Ballard, 419 U.S. 498, 505-08 (1975) (upholding differential tenure periods for male and female naval officers); Kahn v. Shevin, 416 U.S. 351, 355-56 (1974) (upholding a statute granting a larger property tax exemption to women). 
in terms of fairness to women or in terms of effective crime control policy, to sentence female offenders to the same long incapacitative sentences that are thought necessary in the case of potentially violent males?

The gender differences that we are considering are not small. In the Manhart case, the difference in annuity costs between men and women was found to be roughly $15 \% .^{180}$ Sex-specific differences in the propensity for violence in the general population are roughly $800 \%$-eight to nine times higher for men than for women. ${ }^{181}$ When the focus is narrowed to individuals who have already committed one offense, gender differences diminish but remain substantial. Young men begin their criminal careers earlier than young women, they commit more offenses of greater seriousness, and their criminal careers begin to taper off much later than those of the women. ${ }^{182}$ In one study, the propensity for violence

${ }^{180}$ See Manhart, 435 U.S. at 705.

${ }^{181}$ See supra text accompanying note 9; see also 1 Criminal CAREERS AND "CAREER Criminals" 25 (Alfred Blumstein et al. eds., 1986) [hereinafter Criminal Careers] (noting that male arrest rates for violent crimes were 8.3 times greater than female rates for 1980); Darrell J. Steffensmeier, Sex Differences in Patterns of Adult Crime, 1965 77: A Review and Assessment, 58 SOC. FORCES 1080, 1090-92 (1980) (noting that male arrest rates for violent crimes were nine times greater than female rates for 1965 and eight times greater for 1977). Independent victimization data corroborate the arrest data and tend to negate any inference that differential arrest rates are due to differences in willingness to report or arrest female offenders. See Michael J. Hindelang, Sex Differences in Criminal Activity, Soc. PrOBS., Dec. 1979, at 143, 153 (suggesting that "sex is a central correlate of involvement in the crimes examined and cannot be dismissed as simply an artifact of biases in the processes culminating in arrest").

${ }^{182}$ See, e.g., Deborah W. Denno, Gender, Crime, and the Criminal Law Defenses, 85 J. CRIM. L. \& CRIMINology 80, 82, 94, $104-06$ (1994) (basing these conclusions on empirical data drawn from a longitudinal study of biological, psychological, and sociological predictors of crime). Similarly, female offenders released from prison are less likely to commit a subsequent offense and are much less likely to be returned to prison than are men. See BUREAU Of JUSTICE STATISTICS, U.S. DEP'T OF JUSTICE, RECIDIVISM OF PRISONERS RELEASED IN 1983, at 5 (1989) (finding that while $47.3 \%$ of men released from prison in 1983 were reconvicted within three years, only $38.7 \%$ of women were reconvicted); BUREAU OF JUSTICE STATISTICS, U.S. DEP'T OF JUSTICE, RETURNING TO PRISON 4-5 (1984) (finding that in all states except Massachusetts, "the proportion of recidivists among males was substantially higher than for female releasees"). There is some limited evidence to the contrary. In one study of active heroin users, self-reported crime rates were quite similar for males and females, except for burglary, an offense for which the average male offender committed five times more offenses than the average female offender. See Criminal CAREERS, supra note 181, at 67-68. On the basis of this data, the authors speculated that large differences in male and female arrest rates arise primarily from differences in rates of participation in crime, and that once active, females commit crime at rates similar to those of the active males. See id. at 67. This conclusion may, however, be an 
among young offenders who had already committed one offense was three times higher for the men than for the women, and among those who had committed three offenses, $48 \%$ of the men but none of the women went on to commit further crimes. ${ }^{183}$

When the base expectancy of violence is substantially different for the sexes, and when gender gives us predictive information we probably cannot get in any other way, neutrality again becomes, in effect, a form of unjustified discrimination against women. Particularly in the case of sentences that have a large incapacitative component, such as recent "three strikes and you're out" legislation, ${ }^{184}$ there is reason for some discretion to alter the normal sentence on the basis of gender, and perhaps other factors (such as age) that are indicative of low recidivism risk. From this perspective some gender-based differentials in sentencing should have sufficient justification to pass constitutional muster even under intermediatelevel or "strict" scrutiny. As in the case of family ties, there are good reasons to support sentencing rules that are not fully neutral between the sexes.

\section{PRISONS}

Women's prisons are another major growth sector of the criminal justice economy. In 1980, there were over 13,000 women in federal and state prisons ${ }^{185}$ and roughly 9000 in county jails. ${ }^{186}$ We now have over 50,000 women in federal and state

artifact of the focus on the population of active heroin users and appears to differ sharply from the results observed in birth cohort studies that draw upon a more representative sample of both offenders and the general population. See, e.g., Neil A. Weiner, Violent Criminal Careers and "Violent Career Criminals": An Overview of the Research Literature, in VIOLENT CRIME, VIOLENT CRIMINALS 35, 105 (Neil A. Weiner \& Marvin E. Wolfgang eds., 1989) (finding the male rate of recidivism to be approximately three times higher for men than for women in the 1958 cohort); Denno, supra, at 105 (reporting that males are far more likely than females to be chronic repeat offenders and that "female chronics committed fewer and less severe crimes than their male counterparts").

${ }^{183}$ See Weiner, supra note 182 , at 105.

${ }^{184}$ See, e.g., Violent Crime Control and Law Enforcement Act of 1994, Title VII, $\S 70001$, Pub. L. No. 103-322, 55 Crim. L. Rep. (BNA) 2365-66 (to be codified at 18 U.S.C. $\$ 3559$ (c)) (requiring mandatory life imprisonment for defendants previously convicted of either two or more serious violent felonies, or one or more serious violent felonies and one or more serious drug offenses); CAL. PENAL CODE $\$ 1170.12$ (c)(2)(A) (West Supp. 1995) (requiring sentencing to an indeterminate term of life imprisonment in cases where the defendant has two or more prior felony convictions).

${ }^{185}$ See WOMEN IN PRISON 1991, supra note 155, at 7.

${ }^{186}$ See Bureau of Justice Statistics, U.S. Dep'T Of Justice, Correctional 
prisons ${ }^{187}$ and another 40,000 in county jails. ${ }^{188}$ Over one million women are incarcerated in local jails at some point each year. ${ }^{189}$ Since the early $1980 \mathrm{~s}$, the male prison population has grown by $112 \%$, while the female prison population has grown by 202\%. 190

The growing number of women in prison partly reflects the "equal treatment" stance that now governs sentencing. But equal treatment ends the minute the sentencing hearing is over. Once offenders enter the correctional system, men and women face entirely different regimes.

The differences do not always disadvantage women. Physical danger and insecurity are problems for some female prisoners, but these risks seldom compare to the pervasive threats of rape and physical assault that are commonplace for male prisoners. ${ }^{191}$

Female prisoners face other kinds of difficulties, however. Women are typically housed in facilities separate from men. ${ }^{192}$ Moreover, because there are fewer women in prison, the facilities are usually smaller and draw from a much wider geographical area; most states have only one women's prison for the entire state. ${ }^{193}$ In the federal system, the main prisons for women are in West Virginia, Kentucky, Texas, and California, so women from the Northeast and Midwest are often sent over one thousand miles from their homes. ${ }^{194}$

POPUlations In the UNITED STATES, 1991, at 13 (1993) [hereinafter CoRRECTIONAL POPULATIONS] (basing estimates on 1978 data).

${ }^{187}$ See Bureau OF JUSTICE Statistics, U.S. DeP'T OF JUSTICE, Prisoners IN 1992, at 4 (1993) [hereinafter PRISONERS IN 1992].

${ }^{188}$ See CoRrectional Populations, supra note 186 , at 9.

${ }^{189}$ Because jail stays are typically short and because jail census data reflect only the number of inmates in jail at any one time, such one-day census data greatly understate the total number of inmates incarcerated over the course of the year. In 1991, a total of over 1,187,454 women were admitted to jail, and 1,154,110 were released. See Bureau OF JUSTICE STATISTICS, U.S. DEP'T OF JUSTICE, JaIl INMATES 1991, at 2 (1992).

${ }^{190}$ See WOMEN IN PRISON 1991, supra note 155, at 1. text.

191 On the problem of rape in men's prisons, see supra note 13 and accompanying

192 See Nicole H. Rafter, Partial Justice: Women, Prisons, and Social CONTROL 184 (2d ed. 1990) (reporting that of the 80 prisons that held women in $1988,74 \%$ excluded males entirely, and several others were almost entirely segregated by sex).

${ }^{193}$ As of 1988, 44 of the states held all of their female inmates at one or two central locations. See id. at 181.

${ }^{19}$ See Sue Kline, A Profile of Female Offenders in the Federal Bureau of Prisons, FED. Prisons J., Spring 1992, at 33, 36. 
Differences in the programs available to male and female prisoners are striking. Men's prisons in Michigan offer vocational training in twenty areas, but until recently, the women's prison offered only five programs-most focused on such skills as shortorder cooking and handicrafts. ${ }^{195}$ In Idaho, the women's prison offers only two vocational programs, one of which teaches the women how to make decals. ${ }^{196}$ In Louisiana, the only program for women is a sewing class. ${ }^{197}$ In Montana, the women's prison has job slots available to only $18 \%$ of the inmates, and only two programs are offered-sewing and data entry. ${ }^{198}$ The Nevada prison system offers male inmates vocational training in a wide variety of positions, but the women can choose only from domestic jobs. ${ }^{199}$ In Nebraska, the men's penitentiary offers a program leading to a college degree in business administration, while the women's prison offers only a certificate-not a degree-in "secretarial technology." 200

The problem here is not just that women are not offered the same programs provided for men. Consider the programs that are offered to the women: sewing, decals, handicrafts, and cooking. Visiting American prisons in the 1990s is like taking a time machine back to the high schools of the ' 50 s, where the boys took Shop, and the girls learned cooking, baking, and sewing-glorified under the name of Home Economics.

The major problems for women in American prisons are thus numbers and "nature." ${ }^{201}$ The number of female prisoners is no longer so small, but it is still small relative to the number of men in prison. ${ }^{202}$ This means fewer programs and greater separation

${ }^{195}$ See Glover v. Johnson, 478 F. Supp. 1075, 1086-87 (E.D. Mich. 1979).

${ }^{196}$ See RAFTER, supra note 192, at 188.

197 See id. at 187.

${ }^{198}$ See Memorandum of Professor Melissa Harrison Submitted to the Montana House Appropriations Committee (March 9, 1993) (on file with author).

${ }^{199}$ See McCoy v. Nevada Dep't of Prisons, 776 F. Supp. 521, 525 (D. Nev. 1991).

${ }^{200}$ The course in "secretarial technology" was instituted at the women's prison only when a lawsuit challenging unequal educational opportunities was set for trial. See Klinger v. Nebraska Dep't of Correctional Serv., 824 F. Supp. 1374, 1399-1402 (D. Neb. 1993), rev'd sub nom. Klinger v. Department of Corrections, 31 F.3d 727 (8th Cir. 1994), and cert. denied, 115 S. Ct. 1177 (1995). Prior to that time, the Nebraska Department of Corrections had offered no on-site post-secondary education for its female prisoners, although it offered many college courses and degree programs to men. See Klinger, 824 F. Supp. at 1399.

${ }^{201}$ See RAFTER, supra note 192, at 179 (noting that gender stereotypes motivate prison programming and affect staff attitudes toward female inmates).

${ }^{202}$ See PRISONERS IN 1992, supra note 187, at 4 (indicating that women constitute 
from families. Assumptions about women's nature mean that the programs which are offered tend to deny women the skills they need for economic and psychological independence.

The third problem for female prisoners-the third " $N$ "-is inertia. Because male prisoners outnumber women by about twenty to one, ${ }^{203}$ and because male prisoners are much harder to control, men's problems and needs always dominate the agenda of prison administrators. What women get is the fourth "N"-neglect. Or the fifth " $\mathrm{N}$ "-nothing. Yet, what can be done?

\section{A. Constitutional Litigation}

Female inmates have brought many equal protection challenges, but they have won few real victories. The lack of progress seems due, in part, to the kinds of problems that pervade all institutional reform litigation. In 1979, a federal district court found equal protection violations at Huron Valley, Michigan's only women's prison, where vocational and rehabilitational opportunities were substantially inferior to those afforded at the state's prisons for men. ${ }^{204}$ Yet when the court attempted to appoint an independent administrator for the facility, after almost ten years of persistent noncompliance with the court's decree, the Sixth Circuit set aside the order because " $[t]$ he record ... strongly suggests that the district court has not attempted to exhaust a number of methods to enforce its order that are less intrusive. ${ }^{205}$ The appointment of an independent administrator was finally upheld in 1991, fourteen years after the inception of the litigation. ${ }^{206}$

Most class action suits on behalf of female prisoners have ended in settlements, with consent decrees promising improvement in facilities and vocational opportunities. ${ }^{207}$ Yet gains have been modest because the consent decrees have proven difficult to enforce and because states can avoid equal protection problems by simply cutting back on facilities and programs made available to more favorably treated prisoners. ${ }^{208}$

less than $6 \%$ of the inmates in American prisons).

${ }^{203}$ See id.

${ }^{20+}$ See Glover v. Johnson, 478 F. Supp. 1075, 1083-94 (E.D. Mich. 1979).

${ }^{205}$ Glover v. Johnson, 855 F.2d 277, 287 (6th Cir. 1988).

${ }^{206}$ See Glover v. Johnson, 934 F.2d 703, 713-15 (6th Cir. 1991).

${ }^{207}$ See RAFTER, supra note 192, at 201-02.

${ }^{200}$ See Molar v. Gates, 98 Cal. App. 3d 1, 20 (4th Dist. 1979) (finding that the state can comply with equal protection requirements by simply abolishing special privileges afforded male prisoners rather than granting them to women); see also RAFTER, supra 
Beyond these familiar difficulties shared by all reform litigation are a series of problems that grow out of the unique complexities of gender. Does the Fourteenth Amendment require neutrality and equal treatment, or do differences between men and women permit different programs and facilities for the two groups? The contending "isms" of modern feminism do not help much here, and the theoretical debate over "sameness" versus "difference" has shed little light on the issues.

In Canterino v. Wilson, ${ }^{209}$ a federal district court found substantial disparities between the programs available to Kentucky's male and female prisoners. Women had fewer opportunities to qualify for work-release and study-release programs; they were often denied minimum-security classification (and thus denied eligibility for release programs) simply because of an assumption that any social contact with men would lead to pregnancy. ${ }^{210}$ The court held that the women had been denied equal protection, ${ }^{211}$ but the Sixth Circuit vacated and remanded, holding in a brief opinion that there was no proof that the lesser programs had been afforded to the women because of their gender. ${ }^{212}$

The Eighth Circuit was more explicit in Klinger v. Department of Corrections. $^{213}$ The court there held that substantial differences between programs at Nebraska's men's and women's prisons, including vocational training for female inmates that.was limited to traditional "women's" occupations and the denial of college-credit courses, did not violate equal protection because the male and female prisoners were "not similarly situated for purposes of prison programs and services." 214 The court supported that conclusion by noting that, compared to the women's prison, the men's prison housed six times as many inmates, had a higher security rating, and the average stay for its inmates was two to three times longer. ${ }^{215}$ The court also noted that the female inmates were more likely to be

note 192, at 202 (noting that "[e]ven when a court decides in favor of inmates, the result is usually only another long struggle to achieve compliance"); Judith Resnik, The Limits of Parity in Prison, J. NAT'L PRISON PROJECT, Fall 1987, at 26, 28 (noting that "[e]quality can be achieved either by bringing one group up to the other or by reducing the benefits of the group that was "better off").

${ }^{209} 546$ F. Supp. 174 (W.D. Ky. 1982).

210 See id. at 204-06.

211 See id. at 206-08.

${ }^{212}$ See Canterino v. Wilson, 869 F.2d 948, 954 (6th Cir. 1989).

21331 F.3d 727 (8th Cir. 1994), cert. denied, 115 S. Ct. 1177 (1995).

${ }^{214}$ Id. at 731.

${ }^{215}$ See id. 
single parents and victims of physical or sexual abuse, while the male inmates were more likely to be violent and predatory criminals. ${ }^{216}$ Ironically, the fact that the female inmates were less violent offenders, incarcerated for shorter periods, for less serious crimes, became the basis for justifying less generous programs for the women.

The Klinger court's justification for disparate treatment of women in prison stands in sharp contrast to the approach of cases like Reed $v$. Reed ${ }^{217}$ and Craig $v$. Boren. ${ }^{218}$ Many of the differences between the male and female inmate groups are solely the result of the state's decision to segregate them in separate facilities. Differences between the men and the women that are not state created could be relevant for some purposes. I have argued, for example, that the less violent character of female offenders can sometimes justify shorter sentences for them as a group. $^{219}$ Such differences likewise might have a legitimate bearing on the kinds of programs best suited to the needs of particular offenders. But since gender in this context is a crude proxy for the rehabilitative needs of the individual inmate, statistical generalizations, even if valid, cannot justify conclusive gender-based categories that preclude an individual factual inquiry. ${ }^{220}$ Nor, in any event, can any differences between the sexes justify denying women higher education and well-paid jobs that they need as much as men do. In the Nebraska prisons, the programs for women are not only different in content but simply less generous in every respect.

Although the Klinger court's use of dissimilar situations to obviate any equal protection inquiry is surely incorrect, it is more difficult to specify what the nondiscrimination principle affirmatively requires in terms of programs and facilities for female prisoners. The constitutional mandate is obscure, in part, because there is little agreement about what the right policy directions for reform should be. The history of prior reform efforts is not encouraging.

${ }^{216}$ See id. at 732.

217404 U.S. 71 (1971).

218429 U.S. 190 (1976).

${ }^{219}$ See supra notes $161-84$ and accompanying text.

${ }^{220}$ See supra text accompanying notes 163-84. 


\section{B. The Policy Dilemmas and Their History}

Feminist concern for women in prison predates modern feminism by close to a century and mirrors many of the modern themes. Until the latter part of the nineteenth century, female prisoners were usually housed at the same locations as the men, although often in a separate wing or annex of the men's buildings. ${ }^{21}$ Typically, large numbers of women were thrown together in a single large cell, long after the penitentiary system of oneperson cells had been introduced for the men. ${ }^{222}$ The women were also vulnerable to all kinds of exploitation by male prisoners and guards. ${ }^{223}$ In all other respects, female prisoners were ignored. 224

The enlightened response to nineteenth century prison conditions was what became known as the Reformatory Movement. $^{225}$ It stressed rehabilitation for both male and female prisoners, and its guiding principle for the women was separationwomen were to be housed in separate facilities, supervised by a separate staff of female guards and administrators. ${ }^{226}$ The Reformatory Movement was very modern in stressing how women's different needs created a strong case for separate treatment under the benevolent guidance of female supervisors. ${ }^{227}$

221 See Russell P. DOBASH et AL., The IMPRISONMENT OF WOMEN 61 (1986) (discussing the separation of women into exclusive female wings and the appointment of separate female wardens and matrons in British prisons in the mid-nineteenth century); RAFTER, supra note 192, at 7 (noting that the Women's Annex built in 1837, adjacent to the Ohio Penitentiary, was one of the first structures designed specifically for female prisoners); Lucia Zedner, The Prison for Women, in THE OXFORD HISTORY Of THE PRISON: THE PRACTICE OF PUNISHMENT IN WESTERN SOCIETY (Norval Morris \& David J. Rothman eds., forthcoming 1995).

${ }^{222}$ See RAFTER, supra note 192, at 4.

${ }^{223}$ See DOBASH, supra note 221, at 61 (noting that in the mid-nineteenth century United States, "women were held in cramped, insanitary gaols and often subjected to sexual assaults by wardens").

${ }^{224}$ See RAFTER, supra note 192, at 5 (noting that as a general rule "female prisoners almost wholly lacked supervision").

225 See id. at 23-82.

${ }^{226}$ See id. at 184.

${ }^{227}$ See id. at 41-51. Similar themes were evident in the development of the federal government's first prison for women at Alderson, West Virginia. See Claudine SchWeber, "The Government's Unique Experiment in Salvaging Women Criminals": Cooperation and Conflict in the Administration of a Women's Prison-The Case of the Federal Industrial Institution for Women at Alderson, in JUDGE, LAWYER, VICTIM, THIEF: WOMEN, GENDER ROLES, AND CRIMINAL JUSTICE 277, 284-85 (Nicole H. Rafter \& Elizabeth A. Stanko eds., 1982) (noting that a mostly female staff ran Alderson). 
The Reformatory Movement's approach to female prisoners had two serious flaws. First, it linked its conception of women's special needs and special capacities for rehabilitation to a program that stressed training in household tasks and domestic service outside the home. 228 Second, it focused primarily on the needs of white working-class offenders, many of them morals offenders who would not have been in prison at all if they were men who had engaged in similar conduct. ${ }^{29}$ Underclass and minority women usually remained in strictly custodial institutions, often in wings of a male prison, and faced extremely harsh regimes of punishment. ${ }^{230}$

Nonetheless, for all its flaws, the Reformatory Movement was a significant step forward for its time. It survived and prospered from the 1870s until the 1930s. Then a new round of progressive reforms, which focused on corruption in and mismanagement of men's prisons, led to pressures for greater professionalism, more centralized management, and control over the fiefdoms of individual wardens in both male and female prisons. ${ }^{231}$ This development had nothing to do with the women's prisons per se, but it doomed their creativity and independence. ${ }^{232}$ After the 1930s, separate women's prisons remained, but they dealt in punishment; innovative programs were eliminated; women remained separate, and once again they were neglected. ${ }^{233}$

${ }^{228}$ See RAFTER, supra note 192, at 39 (noting that vocational programs focused on training female inmates in domestic skills).

${ }^{299}$ See id. at 35-36 (noting that women were committed to reformatories under long-term sentences on convictions of fornication, drunkenness, and other minor crimes for which men typically were not sent to prison at all).

${ }^{290}$ See id. at 87 (noting that in 1930 Tennessee, "[t]he situation was especially grim for black women" and that "the "Negro Wing' was 'almost constantly overcrowded" (citation omitted)).

${ }^{231}$ See SchWeber, supra note 227, at 287, for an account of these developments in the federal system. In the individual states, women's reformatories were also undermined by the financial stresses of the $1930 \mathrm{~s}$. Throughout the country, prison administrators who were pressured for space in their maximum security prisons transferred out the hard-core female felons who had been held there; these women then had to be housed at reformatories. See RAFTER, supra note 192, at 81-82. The population of less serious offenders who had made up the group in women's reformatories was either severely diluted by the serious felons or was pushed out entirely (and transferred to local jails) to make room for offenders who were not suited to the rehabilitative focus of the reformatory approach. See id.

232 See SchWeber, supra note 227, at 298-99 (chronicling the effects of this change at Alderson, West Virginia).

233 See RAFTER, supra note 192, at 81 (detailing the demise of the Reformatory Movement). 
In the 1970s, reformers again drew attention to the neglect of female prisoners. The 1970s reformers attributed most of the problems to the prevailing policy of separating and centralizing the female inmates. ${ }^{234}$ The preferred solution was called cocorrections, essentially coed prisons, where men and women housed in the same buildings share many programs and facilities. ${ }^{235}$ The idea was to reduce geographical displacement and permit cost-effective delivery of services. ${ }^{236}$ Building on the same insight, a 1985 law review note argued that sexually segregated prisons violate the Equal Protection Clause and that a gender-neutral system of inmate assignment for most offenders is constitutionally required..$^{237}$

Coed prisons have been tried extensively since the 1970 s, but generally they have been a disaster for women. When small numbers of women are dispersed to coed prisons, they are vastly outnumbered by the men at each site. Men's needs dominate, and once again the women get neglected, even more so than before. ${ }^{238}$ There is also a concern about safety and security. You do not have to be a rocket scientist to foresee that there will be security problems when you mix men and women in coed prisons. It is the men who pose the problem, but it is much harder to restrict and supervise the movements of $\mathbf{5 0 0}$ men than to guard closely forty or fifty women. So the women bear the brunt of tight security measures in coed prisons. ${ }^{239}$

By the late 1980s, most women's advocates and prison administrators had lost their enthusiasm for coed prisons. ${ }^{240}$ There remain several mixed-sex prisons, but they retain few features of the coed model: prisoners are tightly separated by sex, and there is little sharing of programs and facilities; ${ }^{241}$ in a few instances the

${ }^{234}$ See Claudine SchWeber, Beauty Marks and Blemishes: The Coed Prison as a Microcosm of Integrated Society, PRISON J., Spring-Summer 1984, at 3, 4-5.

${ }^{235}$ See id.

${ }^{236}$ See id. at 3.

${ }^{237}$ See Rosemary Herbert, Note, Women's Prisons: An Equal Protection Evaluation, 94 YALE L.J. 1182, 1182 (1985).

${ }^{238}$ See RAFTER, supra note 192, at 204 (noting, for instance, that in coed prisons "men forced women out of programs by assuming a right to the best positions").

${ }^{239}$ See SchWeber, supra note 234, at 6-7 ("The burden of upholding this [no physical contact] policy falls heaviest on women inmates who must often be escorted or whose activities must be supervised.").

${ }^{240}$ See RAFTER, supra note 192, at 184 (describing the demise of the coed movement).

${ }^{241}$ New York's Albion Correctional Facility, for example, housed 332 men and 116 women, but the sexes were segregated from one another except in prison industries and food service jobs, college and health service classes, visiting, and certain special 
only coed feature is the housing in a mainly female prison of a small number of much older, minimum security males. ${ }^{242}$ For all practical purposes, the coed movement is now virtually dead. ${ }^{243}$

\section{Toward Effective Solutions for Female Prisoners}

The difficulties of cocorrections drive us back to separating the women, probably-for many states-in a single, centralized facility. That means that the best hope for female prisoners may be a doctrine of separate but equal. No one wants to invoke Plessy $v$. Ferguson ${ }^{244}$ as a shining model, but what is abhorrent for the races in education may be a sensible solution for the sexes in prison.

A separate but equal approach will require us to have a concrete working conception of equality, a daunting task in this context. It makes little sense to afford weightlifting facilities for large numbers of inmates, as in men's prisons, if the women are not interested in using them. Nor does it make sense to deny women programs they do want (like courses in child rearing and prenatal care) just because such programs are not offered to or demanded by men. Inmate needs and preferences are one helpful measure of the kinds of services that should be offered, but this yardstick must be used cautiously, lest programs simply mirror and reinforce role stereotypes that the offenders bring with them to prison. Preparation for jobs and the enhancement of marketable skills should be priorities. Yet effective pursuit of these goals will sometimes require different programs for the women. And expenditure levels for men and women probably should not be held to strict per-capita equality, since program costs can be much higher for small groups of women than for large groups of men.

The search has to be for parity in the services delivered to women and to men. What is needed is what I would call "comparable worth" at the receiving end of the programs. Judged by this standard, the programs afforded to female inmates in the Nebraska prison system, although upheld by the court in Klinger, ${ }^{245}$ should

programs. See SchWeber, supra note 234, at 5.

${ }_{242}$ An example is the $93 \%$ female prison at Clinton, New Jersey. See id.

${ }^{213}$ See RAFTER, supra note 192 , at 184.

24163 U.S. 537, 548(1896) (holding that the separation of passengers of different races into separate railroad cars does not violate the Fourteenth Amendment). Plessy became the basis for the doctrine of separate but equal in education. See Brown v. Board of Educ., 347 U.S. 483 (1954) (overruling Plessy).

245 See supra text accompanying notes 213-16. 
clearly be regarded as constitutionally inadequate. Comparable worth may not be the best solution for wage discrimination in the labor market, ${ }^{246}$ but it does make sense in assessing programs for women in prison.

No one concept or doctrine, of course, will magically solve all of the difficulties. As in the other areas of criminal justice I have surveyed, theoretical conceptions of neutrality, preferential treatment, empowerment, and the like are much less important than the particular strategies used to make feminist goals operational. Plausible ideas can easily backfire unless they are rooted in a close analysis of legal and institutional processes, and unless they are coupled with adequate funding and political support. That makes reform especially tricky in prisons, because when it comes to providing services for drug sellers and other offenders, funding and political support are not in overabundant supply. ${ }^{247}$

\section{CONCLUSION}

The four topics discussed in this Article make clear the overriding importance of particulars. Some may wonder whether the topics are representative-whether I have selected four unusually intractable problems. But if we wanted to pick issues for their intrinsic importance to female victims and female offenders, could we skip domestic violence, rape, sentencing, and prisons?

In stressing the particular and the concrete, I do not aim to deprecate the contributions of theory. As indicated at the outset, my concern about the limits of theory states a dilemma. We need theory, but theory cannot do all the work. The sweeping generalizations of high theory provide excitement in preaching to the choir, but too often they prove inapt, unhelpful, or positively counterpro-

${ }^{245}$ See, e.g., Daniel R. Fischel \& Edward P. Lazear, Comparable Worth and Discrimination in Labor Markets, 53 U. CHI. L. REv. 891, 918 (1986) (noting that comparable worth "has none of the appropriate incentive effects and fails to provide compensation for past wrongs to the appropriate parties ${ }^{n}$ ); Paul Weiler, The Wages of Sex: The Uses and Limits of Comparable Worth, 99 HARv. L. REv. 1728, 1756-79 (1986) (discussing the difficulties of adopting the comparable worth approach); $c f$. Mary E. Becker, Barriers Facing Women in the Wage-Labor Market and the Need for Additional Remedies: A Reply to Fischel and Lazear, 53 U. CHI. L. REv. 934, 940 (1986) (developing a case in favor of comparable worth).

247 See Resnik, supra note 208, at 28 (noting that "[a]s overcrowding increases and interest in rehabilitation diminishes, many vocational and educational programs are reduced ${ }^{n}$ ). 
ductive when the time comes to address the problems of working institutions and the task of producing real improvement for women.

Many strands in contemporary feminism emphasize the importance of context and particulars as sources of insight into social and legal conditions that are oppressive to women. ${ }^{248} \mathrm{~A}$ comparable insistence on doctrinal and institutional specifics is often lacking, however, in the discussion of proposals to redress these conditions. What has been missing from the dialogue, and is now most needed, is a feminism of process and particulars, a recognition that real solutions are likely to lie very deeply embedded in the details.

Because details are critical, and because change itself is guaranteed to bring problems, a natural reaction is that the status quo is not invidious after all. A common response to the feminist challenge is just the point with which I began-the recognition that bringing women into the equation is hard to do. For skeptics, this recognition translates into a do-nothing conclusion. The difficulty of social and legal change is where the discussion stops. My approach in this Article has been different. The difficulty of change was where I started. Change is difficult. But it is also long overdue.

${ }^{248}$ See, e.g., Bartlett, supra note 6, at 849-63 (discussing feminists who emphasize reasoning from context); see also Margaret J. Radin, The Pragmatist and the Feminist, 63 S. CAL. L. REv. 1699, 1707 (1990) (noting that "[p]ragmatism and feminism largely share ... the commitment to finding knowledge in the particulars of experience"). 
